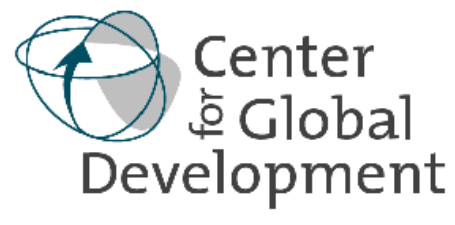

Working Paper Number 141

February 2008

\title{
How Soon Can Donors Exit From Post-Conflict States?
}

\author{
By Satish Chand and Ruth Coffman
}

\begin{abstract}
When can a donor (successfully) exit from an on-the-ground presence in a post-conflict state? The answer, according to the analysis presented here, is in decades: figures well beyond what was originally envisioned when peacekeeping troops were first deployed. In the specific cases of Liberia, Mozambique, Solomon Islands, and Timor-Leste considered here, the best case scenario for successful exit ranges from 15 to 27 years. Successful exit, for the purposes of this paper, entails the creation of the necessary fiscal space to fund the recurrent budget from internally generated revenues. This is a necessary, albeit, not sufficient condition for donor exit. Of essence, however, is the time rather than the dollar value of support provided. An extended donor presence, it is argued, provides the space for the creation, sustenance, and maturation of institutions that are finally able to undergird the state from rolling back into state failure on donor exit.
\end{abstract}

The Center for Global Development is an independent think tank that works to reduce global poverty and inequality through rigorous research and active engagement with the policy community. Use and dissemination of this Working Paper is encouraged, however reproduced copies may not be used for commercial purposes. Further usage is permitted under the terms of the Creative Commons License. The views expressed in this paper are those of the author and should not be attributed to the directors or funders of the Center for Global Development.

This paper was possible by financial support from the Australian Agency for international Development. 


\title{
How soon can donors exit from post-conflict states?
}

\author{
Satish Chand and Ruth Coffman ${ }^{\#}$ \\ Centre for Global Development \\ Washington DC
}

7 March, 2008

JEL Classification Numbers: P6; H10.

Keywords: Post-Conflict reconstruction; Public goods; State-building.

\footnotetext{
\# This paper was written while Satish Chand was on leave at the CGD from the Australian National University. Helpful comments on an earlier draft of this paper from Nancy Birdsall, Chris Blattman, Chakriya Bowman, Ajay Chopra, Michael Clemens, Ron Duncan, Stuart Patrick, Vijaya Ramachandran, Dennis de Tray, David Wheeler, Jeremy Weinstein, and participants at a CGD Research in Progress (RIP) seminar and 2008-GDN Workshop on Fragile States is gratefully acknowledged. Views expressed are those of the authors as is any remaining errors.
} 


\section{Introduction}

In this paper we estimate the time and dollar costs of post-conflict rebuilding in Liberia, Mozambique, Solomon Islands, and Timor-Leste. Our estimates, even under the most optimistic assumptions, suggest that it would be decades, possibly generations, before

post-conflict states are ready to see donors leave. It is not just fiscal space provided by donors that is critical to post-conflict reconstruction but rather the 'breathing space' provided through the on-the-ground presence of donors to permit the creation and consolidation of institutions able to support economic activity and under-gird the state from failure. The last requires time: a lot more time than what donors (and the states themselves) may have originally envisioned. While donor commitment over decades has costs, both direct and induced through problems of moral hazard when such support is assumed to last, it also offers the timeframe to work through strategies to enable an orderly and timely exit.

Let us be specific on what we mean by donor exit. State-viability requires the satisfaction of several necessary conditions. Maintaining a monopoly on the use of coercive force being one, but less obvious is also retaining a monopoly on taxation. Modern states are also expected to be able to provide a number of basic public goods such as law and order, basic healthcare, primary education, etc. We concentrate on a single necessary condition; that of being able to fund the recurrent budget from internally generated revenues, for sovereignty. True sovereignty, as noted by Ghani et al (2007) in the context of Afghanistan, is inconceivable without the above. A necessary, albeit 
insufficient, condition for exit from post-conflict intervention, therefore, is the creation of the requisite fiscal space. While the absence of any one of the necessary conditions is sufficient for non-exit, here we will only focus on the creation of the requisite fiscalspace. Time for donor exit, thus, is realized when the intervened state has acquired the capacity to fund its recurrent expenditure from domestic taxation; developmental assistance may very well continue after donor-exit.

Why this research? Lack of development, described as a failure to "progress toward stable, accountable and national institutions that can meet citizens' needs”, as is common in fragile states, constitutes the greatest contemporary challenge to global prosperity (CGD, 2007: 11). This is consistent with the observation of Fukuyama (2004) that: "weak, incompetent, or nonexistent governments has been and continues to be a source of severe difficulties” within the developing world (page 17). Conflicts have invariably weighed down development (see table 1). This research has been motivated by the void in the literature and within policy circles on a clear time frame and resource requirements for post-conflict reconstruction, including the rebuilding of the nation state itself. Donors have on the whole been vague about the length of their commitment to reconstruction in post-conflict states. They have been equally vague about the costs (and benefits) of such interventions. Interventions into post-conflict states, ongoing as they are, have however guzzled up a significant amount of resources. Not withstanding the poor quality of data on resources expended in post-conflict reconstruction, they have been expensive. Our calculations shows some $\$ 16.91$ billion dollars had been pledged for reconstruction purposes in a dozen post-conflict states (see tables $2 \& 3$ ). This, moreover, may be an 
underestimate since pledging conferences have a time horizon of a few years only.

Various missions into Haiti have cost the international community $\$ 1.3$ billion, while interventions in Liberia have cost around \$2.7 billion (see figures reported in tables 2 and 3). Trends, moreover, suggest that post-conflict interventions may be far from over yet (see Fearon and Laitin, 2004; DFID, 2005).

While state building is acknowledged as a time consuming and highly complex process, the imperatives for doing so in post-conflict states are stronger than elsewhere (Fukuyama, 2004; CGD, 2007). A Commission set up by the US Government notes that:

"War-torn societies are not healed in 12 months; weak and failing states cannot be rendered capable in two years. Transforming countries that have suffered decades of misrule, political dysfunction, economic distortion, and unchecked violence requires building consensus in the U.S. Government around strategies that extend beyond our one-year budget cycle and presidential elections that occur every four years." (HELP Report, page 9; December 7, 2007, http://helpcommission.gov/).

Little research to date has informed policymakers on what to do and how long to remain engaged in a post-conflict rescue, however. The IMF, for example, notes that:

“Given Liberia's resource constraints and low level of income, restoration of physical infrastructure and achieving sustained high economic growth will require substantial external support for an extended period." (IMF, 2006: 35 - emphasis added)

The Fund, however, does not define what it means by 'substantial' or 'extended'. For its part, the OECD’s Principles for Good International Engagement with Fragile States mentions that "capacity development in core institutions will normally require an engagement of at least ten years.” ${ }^{\prime 1}$ USAID’s Fragile States Strategy does not mention time-frames, while the World Bank’s IDA 14 Reauthorization allows the provision of

\footnotetext{
${ }^{1}$ Principles for Good Engagement with Fragile States. (April 2007). http://www.oecd.org/dataoecd/61/45/38368714.pdf
} 
extra resources to post-conflict states for seven years. ${ }^{2}$ Bilaterally, the situation is worse. The Australian government, for example, had provided for four years of budgetary funding to the Regional Assistance Mission to the Solomon Islands (RAMSI). ${ }^{3}$ The Prime Minister of Australia, however, had promised that RAMSI would remain 'until the job was done' (EPG, 2005; page 10). What entailed the job being done was not clarified. Furthermore, it is now up to the new government to decide as to what RAMSI's time frame may be.

This paper makes two original contributions. First, it computes time and resource costs to exit from four post-conflict states. The figures on the length of time that donors need to remain engaged in post-conflict states ranges from 15 years for Liberia to 27 years for Timor-Leste. These figures are purposefully conservative given the several optimistic assumptions made in generating them. They, nonetheless, are startling as they far exceed what has been proposed by donors. The World Bank’s 7 year plan for its engagement in post-conflict reconstruction falls short by a factor of two for all of the four post-conflict states studied here. If our computations on the length of engagement of donors in postconflict rescue are to be believed, they throw up several fresh options on strategies to be pursued. Some thoughts on what may be done differently when the length of engagement in post-conflict reconstruction is known in advance are proposed as the second original contribution of this paper.

\footnotetext{
${ }^{2}$ USAID Fragile States Strategy (2005). http://www.usaid.gov/policy/2005_fragile_states_strategy.pdf. World Bank’s Summary of Performance-Based Allocation System for IDA14 http://siteresources.worldbank.org/IDA/Resources/ANNEX1CPIA.pdf

${ }^{3}$ EPG's External Assessment of the Regional Assistance Mission to the Solomon Islands. http://www.ramsi.org/files/epg_report final.doc.
} 
We use the cases of four post-conflict nations to generate some explicit figures on 'time to donor exit' and the benefit-to-cost ratios of such undertakings. Our figures, reported in table 5, are a sobering reminder that successful exit from post-conflict societies will, even under the most favorable assumptions, entail a lengthy donor-presence and cost several hundred million dollars. Is this worth the effort? Again, our figures suggest that the answer is in the affirmative for three of the four states scrutinized. Mozambique, a postconflict nation furthest down the path to exit, and at current rate of growth of income would require donor support for at least another five years and funds to the tune of $\$ 0.8$ billion (at 2005 prices and from 2005 onwards). Liberia, even if able to mimic the stellar performance of Mozambique, will need another 13 years (from 2005) and some $\$ 0.8$ billion to see donors off. Solomon Islands on the same count will need some 23 years and a total of $\$ 2.1$ billion in donor support. Post-conflict rescue in Timor-Leste will require 21 years (from 2005) of donor support and cost some \$2.1 billion. All of the dollar-support, moreover, would be just for the recurrent budget. This, on its own, is not sufficient for exit, but its absence is sufficient reason for continued donor-support.

The rest of the paper is structured as follows. Section 2 highlights the links between state strength and fiscal capacity, arguing that the creation of fiscal space is critical to reducing fragility. It is the time taken to achieve the necessary fiscal space to fund recurrent (State) services that determines when donor-support becomes redundant. Section 3 considers post-conflict assistance in four states as a demonstration of the methodology discussed in the previous section. Section 4 draws policy implications from the findings 
of the previous two sections. Conclusions and suggestions for areas of further research bring the paper to a close.

\section{State strength and fiscal capacity}

Why is it that state rebuilding in the $21^{\text {st }}$ Century is so much more resource intensive than similar efforts of the previous Century? The Marshall Plan, the most celebrated of such rescues, for example, cost a paltry $\$ 13$ billion (equal to some 3 percent of the combined GDP of the recipient nations) and lasted a measly 3 years. De Long and Eichengreen (1991) attribute the success of "history’s most successful structural adjustment program” not so much to the transfer of resources but to the creation of market-friendly institutions. This observation resonates with the more recent claims from institutional economics (Olson, 1982; North, 1991; Acemoglu, 2005) that 'institutions rule' (Rodrik, et al 2004). While no two interventions are identical, the growing body of evidence on the critical role played by institutions in growth and development provide lessons on what may be done to undergird state failure. The record on institution-building in intervened states is less than impressive, however.

But why do states fail in the first place? Chauvet $\underline{\underline{e t}} \underline{\underline{a l}}$ (2007) attribute poor policies and governance that characterize failing states as: “observable manifestations of a dysfunctional society” (page 3). They thus argue for interventions, much akin to those of the Marshall Plan, to change policies and governance in the intervened states. A major difference, however, between the recipients of aid via the Marshall Plan and post conflict societies being assisted in the $21^{\text {st }}$ Century are that the former had the institutions - 
namely, the legal system and the enforcement mechanism in place - and the memory (norms) of a well functioning state, while prolonged conflicts have eroded both of the above in the latter group of countries. Prolonged presence of donors in post-conflict societies, therefore, may be as valuable as the dollar value of resources expended in resurrecting these norms in state rebuilding.

The key proposition of this section is that fiscal capacity is a necessary prerequisite to the restoration of state strength. Fiscal capacity in this context refers to the ability of the state to raise sufficient revenues from internal sources to be able to fund the minimally required state services. The most basic of these services comprises the ability to maintain law and order, which in turn requires the State to maintain a monopoly on the use of force, and the capacity to regulate private economic activity. Furthermore, the norm for modern states has been that they fund basic public provision of primary education and healthcare, and some minimal level of physical (transportation and communications) infrastructure to induce trade and commerce. All of the above need resources. States fail when they lose their ability to meet these basic obligations. For the purposes of this paper we assume that some minimal level of fiscal space, that is, recurrent revenues, is necessary for State-sustenance. The actual dollar value required, even on a per capita basis, differs markedly across societies, as shown in the next section. Weak states, thus, comprise those lacking: "the power to tax and regulate the economy and to withstand the political and social challenges from non-state actors” (Acemoglu, 2005: 1199). Those states that succumb to violence from rival organizations descend into civil war and with it lose their fiscal capacity to sustain themselves - this we denote as the 'bad equilibrium'. 
Climbing out of this situation on its own becomes close to impossible for the afflicted state.

There is now a large and growing body of evidence suggesting that state services such as institutions to protect property rights is the minimum necessary for successful private enterprises. Much of this literature stresses the role of public institutions in reducing transaction costs in a market economy. Thus a growing economy that is able to fund improved public provision reaps the benefit of further growth, enjoying a virtuous cycle. Weak states are often caught in the opposite spiral; state failure results when the state is unable to provide security to its citizenry. GDP and thus tax revenues collapse; evidence for this is shown in the next section. Fiscal strength such as the power to tax and economic performance are not necessarily linearly related, however. ${ }^{4}$ A leviathan ruler with powers to expropriate resources from the citizenry has incentives to invest in public provisions only under limited circumstances (see Acemoglu, 2005 on this). But fiscal capacity for the weak (post-conflict) states considered in this paper, in all likelihood, lies below rather than above the optimal level a la Acemoglu (2005). A post-conflict state, thus, may have landed itself in a trap: lacking the fiscal space to provide the minimal levels of public goods to induce enterprise that in turn keeps it starved of the necessary resources to climb out of its predicament on its own volition. External intervention, thus, provides the opportunity to break out of this trap. Doing so, however, requires both the creation of the necessary fiscal space and the institutions to undergird economic activity. But why should the externals intervene, particularly when doing so is expensive?

\footnotetext{
${ }^{4}$ Acemoglu (2005) shows that there may be an 'optimal' level of state strength and that this is high only in 'consensually strong states'.
} 
Anarchy, as shown by Leeson (2005), may be efficient in some instances. We address this issue later in the paper.

The time required for donor exit from a post-conflict state is computed as that required for the creation of the requisite fiscal space. That is, the year of donor exit, ' $t$ ', is when

$$
\mathrm{G}-\mathrm{R}(\mathrm{t})=0
$$

where G denotes the steady state level of recurrent expenditures, while domestically generated budgetary revenues is given as

$$
\mathrm{R}(\mathrm{t})=\mathrm{T}(\mathrm{t}) \mathrm{Y}(\mathrm{t})
$$

where $\mathrm{T}$ denotes tax-take as a share of GDP (Y). The total cost (C) of donor support to ' $\mathrm{t}$ ', the time to donor exit, is given by

$$
C(t)=\sum_{i=0}^{t} \frac{G-R(i)}{(1-\delta)^{i}}
$$

where $\delta$ denotes the discount rate and ' 0 ' is the beginning of the post-conflict period. This 'breathing space' provided through to 't' by the donors, moreover, may be the minimal necessary to under-gird subsequent state-failure.

Unlike the Marshall Plan, the task of building institutions such as the norms of behavior, regulations, and agencies to enforce these are likely to take considerable time, a point made in a more general context by Besley and Persson (2007). Both the political and economic institutions require rebuilding in post-conflict states (Acemoglu, 2005). Here, for reasons of tractability, we focus exclusively on the internal revenue raising capacity of the state, realizing that growth of GDP necessitates the creation and sustenance of the institutions to undergird enterprise. We also assume that peace is maintained post- 
conflict; an assumption that has empirical support (Gilligan and Sergenti, 2007). Thus, well-planned and sufficiently-timed interventions into post-conflict states have the potential to provide the breathing space for the economies subject to intervention to grow sufficiently to be able to fund their (steady-state/recurrent) obligations. Donors may leave once such a stage has been reached, but developmental assistance may continue. We next apply this methodology to compute the time to exit in four post-conflict interventions.

\section{Empirics}

Not withstanding problems with data quality, the cost of state provisions differs considerably across nations. The capacity to tax, similarly, is just as varied. This section uses all available information to compute the requisite (minimal) fiscal space for donorexit. Figure 1 shows the levels of average per capita government consumption expenditure plotted against average per capita GDP for the 115 countries for which this data is available (see data appendix for data sources and variable descriptions). The two are strongly correlated with the correlation coefficient of 0.95 . Countries with high per capita GDP, on average, collect more revenues and thus spend more on a per capita basis on government consumption. Two observations from the cross-country data are pertinent to the analysis that follows. First, revenue raising powers of a state depend more on per capita income rather than the tax-take as a share of GDP. Second, per capita government expenditure differs enormously across states, even for those that may be considered as being strong. The former observation points to the fact that raising fiscal space, in the main, is a challenge of raising income (GDP) rather than raising tax effort. The second 
suggests that the steady-state level of recurrent outlays is country-specific where international norms are unlikely to apply. ${ }^{5}$

Fragile states, moreover, have on average not only lower levels of per capita GDP but also lower ratios of government expenditure and revenues to GDP. Thus, fragile states are deficient in revenues and tend to spend less than their non-fragile counterparts on state services. The lower expenditures and revenues peculiar to weak states, as discussed in the section above, is not evidence of causation but that of the joint determination of per capita income, tax collections, and outlays on 'state services'. ${ }^{6}$ An intervention into a failed state, thus, provides the opportunity to break out of the trap of limited fiscal space and state weakness. The foreign intervention, in other words, can be thought of as a 'big and sustained push' to get the post-conflict state out of the 'bad' to the 'good'

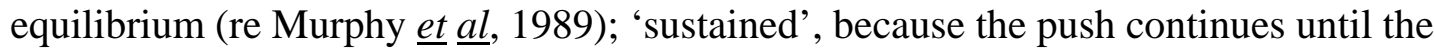
intervened state attains the requisite fiscal space to sustain its recurrent provisions. We next consider what may constitute the fiscal space that would render a post-conflict state free of the need for continued donor support to its recurrent budget.

Here we will concentrate on recurrent (that is, steady-state) levels of government expenditure, abstracting from capital outlays and those associated with humanitarian assistance. The level of recurrent government expenditure on a per capita basis, as shown above, varies considerably across countries. This difference is due to several factors including country-size, population density, the degree of heterogeneity in the population,

\footnotetext{
${ }^{5}$ Explaining why government expenditures differ so massively across countries is part of ongoing research ${ }^{6}$ Summary statistics on the cross-country data used for this analysis are given in Appendix Tables A1(a) to (c).
} 
the level of development, and the degree of openness of the economy (see Alesina and Spolaore, 2003; Alesina and Wacziarg, 1998; and Rodrik, 1996). While fragile states, on average, have lower levels of per capita government consumption than others, the requisite level of expenditures to sustain a functioning state would be unique to the country in question. The minimal level of recurrent expenditure that will enable Mozambique to sustain itself as a functioning and viable state, for example, is unique to Mozambique. Our challenge is to get an estimate of this figure; an issue we address next.

We use the level of recurrent expenditure as of 2005, a 'normal' (non-event) year in the four countries considered here as that necessary for state viability. This is a critical and strong assumption for our analysis, thus extreme care has been taken in constructing this figure (see Appendix II for details on how this figure was constructed for the individual post-conflict countries considered here). We have also undertaken robustness tests of our estimates on time to and cost of donor exit on alternate (historical) values for the growth parameter. A narrower interpretation of our results would be the time necessary to enable the four post-conflict states studied here to be able to fund their recurrent outlays as of 2005 from internally generated revenues.

We consider the cases of four post-conflict nations, namely: (i) Mozambique; (ii) Liberia; (iii) Solomon Islands; and, (iv) Timor-Leste. All are at different stages of post-conflict reconstruction. Their selection was anything but random. Mozambique has been selected as the model post-conflict state and one furthest along the path to exit on account of progress made in being able to fund its recurrent budget. Liberia and Solomon Islands 
were chosen due to the availability of data, and the fact that post-conflict interventions began in 2003 and only a month apart, thus providing several useful comparisons. Timor-Leste was chosen, once again, for the availability of data and the fact that the nation may have access to resource rents to fund its recurrent budget but yet be in need of donor support for reasons other than for donor support to the recurrent budget as explained in some detail later. Each of the countries has their idiosyncrasies, thus the individual cases are considered following some general remarks.

Figure 2 shows the evolution of per capita GDP ten years before and ten years after the year of intervention, when such data is available, for the above-mentioned countries. The horizontal axis plots time with the Year 0 denoting the year when peacekeepers first landed in the country and is interpreted as the commencement of the post-conflict era; that is, when conflict was brought to an end through external intervention. In the case of Mozambique, Year 0 denotes 1992 when a UN negotiated peace agreement brought a long running civil conflict to an end. In the case of Timor-Leste, Year 0 is 1999 when UN-sponsored peacekeeping troops, led by Australia, arrived. For Liberia and Solomon Islands, Year 0 is 2003. The vertical axis in Figure 2 shows per capita GDP, normalized to 100 at Year 0, for each of the four countries.

Figure 2 shows that per capita GDP for Mozambique was on a roller coaster ride in the decade before cessation of conflict, but has grown at an annual average of 5 percent since then. Per capita GDP had doubled in the 14 years since the end of conflict. Even the devastating floods of March 2000, the worst recorded in half a century, did not place a 
dent on this growth. However, the large humanitarian assistance that followed this disaster, shown in Figure 3, would have helped maintain the high rate of growth of GDP. Per capita GDP in Solomon Islands peaked some 7 years before the end of conflict (that is, in 1996), following which it rolled back to some 70 percent of its peak just before the conflict ended. The sharpest fall in per capita GDP took place during the civil war; that is, from Year -4 (1999) to Year 0 (2003). The recovery since then has been at an annual average rate of 2.5 percent.

The collapse of per capita GDP in Liberia extends well before the 10-year window prior to the cessation of conflict; Figure 2 masks this long-term decline. Figure 4 shows the simultaneous collapse in Liberian per capita GDP: from the high of US\$745 (at 2000 prices) in 1980 to the low of US\$57 in 1995 . Per capita government consumption peaked at US\$168 (at 2000 prices) in 1982 and had fallen to US\$10 (at 2000 prices) in 2003 . Per capita GDP rose sharply from 1995 (Year -7 in Figure 2) to 2000 and then crashed in the year just preceding the UN intervention. The record for Timor-Leste is less than enviable with per capita GDP heading south following a spike lasting two years after the arrival of the peacekeepers. While the reasons for the changes in GDP for each of the abovementioned are a lot more complex than what has been discussed thus far, the purpose of Figure 2 is simply to provide the best case scenario, that of Mozambique, that a postconflict state can expect in terms of the rate of growth of per capita income. Our first assumption involves overlaying the per-capita growth record of Mozambique, as the best case post-conflict scenario, on the remaining three post-conflict states. We also use the 5 
percent per annum growth rate to extrapolate per capita GDP for Mozambique for future years.

Our second squabble with the data has been in working out the extent to which donors have funded the recurrent budget of post-conflict states. This has been less than a straight forward exercise. Donors, on the whole, are notoriously bad in providing data on the level of support afforded to a country and even more so when it comes to the finer details of the particular activities funded. We have used budget records, wherever available (see Appendix II for further details), and supplemented these with IMF sources and particularly their Article IV mission reports to decipher the levels of donor support to the recurrent budget. Finally, we assume that donor exit is possible when the State is in a position to fund its recurrent budget with domestic taxation. Fitting this final piece of the puzzle has been the least of the concerns since data on tax take as a share of GDP is available from the IMF. Given the peculiarities of the data, the differences in the levels of per capita recurrent outlays, and the share of taxes and other sources of finances for the individual governments, we next consider the post-conflict states individually. We begin with the case of Mozambique, given its role as the 'model' post-conflict state furthest along the path to donor-exit. We later repeat this exercise for Liberia, Solomon Islands, and Timor-Leste.

(i) Mozambique Mozambique is the model post-conflict economy well on its way to seeing donors off in the next decade. Since the end of its civil war in 1992, aggregate GDP has grown at an 
average annual rate of 8 percent, or, in per capita terms, of 5 percent. The headcount index for poverty fell from 69 percent in 1997 to 54 percent in 2003. Figure 3 shows government consumption and aid receipts on a per capita basis from 1980 to 2005. Per capita aid receipts peaked at $\$ 139$ in 2002, but a significant proportion of this aid was for relief in the aftermath of the devastating floods. We have drawn on budget estimates and DAC data to reach a recurrent per-capita government expenditure figure as of 2005 of $\$ 67.20$. This, we assume, is the required steady-state value for the level of recurrent expenditure necessary to sustain a functioning Mozambican state. Thus, the time for exit of donors from Mozambique is reached when this minimal value of revenues is generated from domestic taxation. Policymakers have indeed expressed their desire to achieve such an outcome in the near future (see IMF, 2007: 20).

On the revenue front, tax revenues raised as of 2005 amounted to 13.6 percent of GDP. The government has expressed its intention of ratcheting up tax take as a share of GDP by half a percentage point per year over the near future; this is to be achieved through broadening of the tax base and via improvements in revenue administration (IMF, 2007: 15). Thus, we use the starting values for per capita GDP and average tax take as a percent of GDP as for 2005 and roll this forward on the assumption that tax take as a share of GDP rises half a percentage point each year while per capita GDP growth is maintained at 5 percent per annum. On these assumptions, government recurrent per capita expenditure as of 2005 of \$67.20 is raised from domestic sources alone in 2010. Thus, our criteria suggest that donors can exit Mozambique in 2010. ${ }^{7}$ The shortfall in

\footnotetext{
${ }^{7}$ The time to exit involves a search for ' $t$ ' (the year) when the minimal recurrent outlays for state viability is funded with domestic taxation.
} 
recurrent outlays up until then, this being the revenue-gap, is assumed to be met by donors (re equations 2 and 3). The total value of this support, in net present value terms as of 2005 at a discount rate of 5 percent and using population growth rates for 2005, amounts to $\$ 0.81$ billion (at 2005 prices).

In other words, our model post-conflict country would have taken a total of some 18 years since the cessation of fighting to be in a position to be able to fund its recurrent provisions for state viability using domestic taxation. Figure 5 depicts the evolution of per capita GDP, tax revenues, tax take as a share of GDP, and the revenue gap to fund recurrent provisions. It also shows that the gap between recurrent per capita government expenditure and tax revenues generated locally disappears by 2010; thus, the implied date for exit by donors. The final task for Mozambique is in figuring out if such an investment would be worth the trouble. ${ }^{8}$ Chauvet et $\underline{\text { al }}$ (2007) estimate that the total expected cost of state failure for a typical failing state (with a population of 15 million), just in terms of loss of GDP for the residents, is \$28 billion (page 7); they then add on another \$3.5 loss in GDP due to a civil war and a further \$3.7 in terms of increased mortality from the war. We read the above total of $\$ 35$ billion cost of state failure as the benefit of successfully rescuing a post-conflict state from rolling back into conflict. ${ }^{9}$ The \$0.8 billion cost of lifting Mozambique to the 'good equilibrium' is compared to the population-weighted benefit of $\$ 47$ billion (that is 20/15* $\$ 35$ billion), derived from Chauvet $\underline{a t} \underline{\text { al }}$ (2007), gives a benefit to cost ratio of 57: 1. In other words, a probability of success of the intervention of 2 percent or more would be a sound bet for a risk-neutral

\footnotetext{
${ }^{8}$ We do not consider past donor support as this is 'sunk' costs for the purposes of this analysis.

${ }^{9}$ These figures must be taken as indicative only as they are generated with equally conservative assumptions.
} 
intervener. These are indeed very crude estimates, but they suggest that continued support to the recurrent budget in Mozambique has a financial case for it. More importantly, the probability of success can be influenced by the interveners, a point taken up in some detail in Section 4 of the paper.

(ii) Liberia

Liberia's is a sad story. The nation is recovering from fifteen years of intermittent civil war that ended in 2003. Per capita GDP fell 92 percent between 1980 and $1995^{10}$; this is one of the largest recorded collapses in any economy ever (Radelet, 2007). IMF (2006) notes that:

"[t]he country’s physical infrastructure has been largely destroyed, government institutions lack the basic capacity for economic management, and the country's once considerable human capital has been significantly eroded.... over 80 percent ... of the population subsists on less than US\$1 a day, with no access to basic health, education, and other social services." (IMF, 2006: 5)

Ms. Antoinette M. Sayeh, the Minister of Finance of the Republic of Liberia noted in her statement to the Executive Board Meeting of the IMF on April 26, 2006 that:

"Liberia is emerging from two decades of economic mismanagement and 15 years of brutal civil war which devastated our economy and human assets, leaving deep scars in our social fabric. Our peace is still very fragile, made possible in large measure by the presence of some 15,000 United Nations troops. Electricity is the privilege of the fortunate few who own and can purchase fuel for generators, as is running water. More than 80 percent of our labor force is unemployed while basic education and health care remain unavailable or unaffordable for most of our children and people. There are still large numbers of internally displaced persons and ex-combatants who need to return to their homes and who require reintegration into Liberian society. We have accumulated huge external and domestic arrears, and our revenues and resources have been pillaged.”

${ }^{10}$ Data sourced from World Development Indicators - see Data Appendix for details. 
These statements are succinct summaries of the plight of the state and its inability to provide basic 'state services'. The plight of the people is worse, however. Some 46 percent of the population fell below the minimal level of dietary energy consumption while youth (that is, the 15 to 24 year cohort) illiteracy rates were reported at 71 percent (figures for 2003 from IMF (2006), page 65). These are sobering statistics and a poignant reminder of the devastation of conflict on the wellbeing of the afflicted population. They equally point to the daunting challenges of rebuilding a post-conflict state. The authorities, both in Liberia and within the donor agencies, are cognizant of these challenges. The IMF (2006) notes that: “[i]n light of external and domestic financing constraints, the authorities agreed that the budget should remain balanced for some time”; but then proceeds on to admit that rebuilding of Liberia would require “sustained external financial and technical assistance” (IMF, 2006: 10). We next compute what the length of donor engagement and value of this support may be.

An analogous methodology to that employed for Mozambique is used to generate the minimal time and budgetary support necessary to enable the economy to generate sufficient resources internally to fund its steady-state level of recurrent fiscal expenditure. The starting values for per capita GDP (of \$167) and average tax take as a percent of GDP (of 14.5\%) is that for 2005. The values for the subsequent years are generated with the assumption that tax-take as a share of GDP rises by half a percentage point each year and that per capita GDP growth is maintained at 5 percent per annum. Per capita recurrent government expenditure for 2005 of \$63.13, at 2005 prices, has been assumed. This value is raised from domestic sources under the above assumptions by 2018; that is 
in 13 years and at a total cost of $\$ 0.76$ billion (at 2005 prices and summed from 2005 with an assumed annual discount rate of 5 percent). The benefit-to-cost ratio, using the same methodology as that for Mozambique, is 10:1 (that is, $\$ 7.7$ billion: $\$ 0.76$ billion). Alternatively, a probability of success with odds greater than one-tenth would be a bet taken up by a risk-neutral intervener.

\section{(iii) Solomon Islands}

Peacekeepers comprising some 2,200 police and military personnel, led by Australia, landed in Honiara on 23 July 2003; just a month before the UN intervened in Liberia. Thus, these two post-conflict states provide many useful comparisons in state rebuilding. Logging, mostly of native forests and at an unsustainably high rate, as of 2006, accounted for some 70 percent of exports, 15 percent of domestic government revenues, and 10 percent of GDP (IMF, 2007). On current estimates, the stock of exportable stock of logs will run out by 2014. Current government expenditure as of 2006 was approx 33 percent of GDP (IMF, 2007: 10) Aid as a share of GDP, according to data from WDI, accounted for some 45 percent of GNI in 2004 and had climbed to 66 percent by 2005. Grants from donors for developmental expenditure, net of police and military spending, amounted to some 35 percent of GDP (IMF, 2007; Table 3). The level of donor support, high as they are, may be an under-estimate since the Fund notes that:

"Development grants and grant-financed development spending are currently administered by donors, and hence are not under the direct control of the government. They exclude police and military spending, but include noncash grants. Data on aid flows are now being captured more accurately, and they indicate much higher levels than previously estimated." (Footnote number 1; page 27) 
The contribution to growth of aid, as shown by the literature, faces strong diminishing returns such that even in the best policy environments, aid has zero impact on growth at a ceiling of 45 percent of GDP. ${ }^{11}$ Aid has probably reached saturation point in Solomon Islands and is more than likely to be wound down in the near future. The risk with the rescue of the Solomon Islands state, as shown by the broader international experience (see Elbadawi et al, 2007), is that aid will be withdrawn too quickly; and, if accompanied with a fall in log exports could cramp fiscal space rapidly enough to be destabilizing. The IMF, consistent with their standard mantra, has recommended that the local authorities: "maintain fiscal discipline and create additional fiscal space for priority spending within a medium-term framework" and that: "current expenditure would need to be reduced by some 3 percentage points of GDP, starting in 2008, to keep the primary domestic surplus at around $1 / 2$ percent of GDP over the medium term” (IMF, 2007: 8 \& 9). We return to the absurdness of these recommendations later.

We once again run simulations on the minimal time necessary to generate the fiscal space for Solomon Islands to be able to fund its recurrent budget from internal sources. In terms of the parameters used, the major difference is that the per capita cost of providing state-services in Solomon Islands is considerably larger and tax-take as a share of GDP considerably higher than the corresponding figures for Liberia and Mozambique (as well as Timor-Leste as shown later). The starting value for per capita GDP of \$624 and average tax take of 24.7 percent of GDP is for 2005. The values for the subsequent years are generated with the assumption that tax-take as a share of GDP rises by 0.2 percentage

\footnotetext{
${ }^{11}$ Clemens and Radelet (2003), particularly their table 2 on page 23, provide an excellent survey of this literature.
} 
point each year and that per capita GDP growth is maintained at 5 percent per annum. While the lower annual increment on tax-take than that assumed for Mozambique, Liberia, and Timor Leste (as shown later) has been assumed simply because Solomon Islands may be hitting the ceiling on this parameter, there are other policy motivations for doing so and these are explained in the next section.

Per capita recurrent expenditure inclusive of donor support, even when provided outside of the budget, is estimated at $\$ 545$ (see notes on how this figure has been reached in Appendix II). This cost is some 8 times the corresponding figure for Mozambique and Liberia, and nearly thrice that of Timor-Leste. Fiscal space to enable the generation of $\$ 545$ per capita from internal sources at an assumed 5 per cent per capita growth rate of GDP and with tax take rising by 0.2 percentage point from the 24.7 percent from 2005 takes a good 25 years; that to 2028. Donors in the mean time would have funded a total revenue gap, in 2005 US\$ as of 2005 with an assumed discount rate of 5 percent, to the tune of $\$ 2$ billion. The cost of not undertaking such a rescue, using population weighted figures from Chauvet $\underline{a t} \underline{a l}$ (2007), would be $\$ 1.2$ billion (that is, $\$ 35$ billion/15*0.5) with a benefit to cost ratio of 1: 2 (see table 5). The rescue of Solomon Islands, thus, does not have the same strong financial case as that for the previous two. Diluting this case even further is the fact that the growth estimates for per capita GDP are well above those experienced over the post-conflict period (see table 6). The message here is not that the rescue of Solomon Islands ought to be suspended, but that costs of state services need greater scrutiny given the inflation factors involved when compared to Mozambique, our model post-conflict state. Incidentally, the state will in all likelihood face considerable 
pressure over time as logging stocks diminish. A simultaneous departure of the donors with an export collapse would be a recipe for a rollback into state failure through fiscal depletion.

\section{(iv) Timor-Leste}

An exercise analogous to that of the above three was also undertaken for Timor-Leste. There are two issues unique to Timor-Leste: (i) it has better data on donor support to the recurrent budget (see IMF, 2007c); and, (ii) resource rents are projected to be sufficient to fund the estimated revenue gap. On the latter, we concentrate solely on the growth of the non-mineral economy to generate the requisite fiscal space. Resource rents, while providing revenues to the budget, are ignored as they create just as many problems and in the case of countries afflicted by the 'resource curse', even more. The initial value of the non-oil per capita GDP figures has been used in the computations. Other than the exceptions noted above, similar assumptions are made as for Mozambique in rolling the estimates for per capita GDP and tax revenues forward in time. Assuming a growth rate of per capita non-oil GDP of 5 percent, the recurrent per capita government expenditure of $\$ 197$ (at 2005 prices) of 2005 will be funded from non-oil GDP by 2026 and at a total cost of $\$ 2.1$ billion (at 2005 prices summed from the Year 2005). The WDI reports population growth rate of 5.5 percent, but this parameter cannot be taken seriously; thus an alternative estimate from the World Factbook of 2.13 percent has been used. The benefit to cost ratio just evens out for Timor-Leste, but this may not be a constraint in this case as explained next. 
Unlike its post-conflict counterparts, oil and gas developments are projected to raise budgetary revenues of $\$ 3$ billion over the 2006 to 2010 period (IMF, 2007). Does this render donor support redundant? We do not believe so. We are not even sure if the nation can borrow on this 'future fund'. As discussed in some detail in the next section, the key result from these simulations is the longevity of donor presence in post-conflict states to create the institutions that would undergird against a rollback to conflict on exit of externals. Large resource rents and the political competition they induce, raise the risks of conflict, particularly in countries with weak institutions (see Collier, 2007b for an extensive survey). Thus, Timor-Leste may not need the donor funds to meet the revenue gap estimated above, but will still need their on-the-ground presence for a good quarter century at least, to provide the timeframe for creation and maturation of institutions to prevent a rollback into state failure. Furthermore, this timeframe may be an underestimate since institutions to manage the potential adverse 'Dutch disease' and 'resource curse' effects of the impending mineral boom also need to be imbedded.

The empirics thus far has produced the following results: (i) successful exit from postconflict states, even under the most favorable assumptions, involves engagements exceeding a decade and more likely to have a time horizon of a quarter century; (ii) purely on benefit to cost considerations, interventions into two of the four post-conflict states considered are justified, even if the odds of success are 50 percent or less; (iii) Timor-Leste fails on the above but may already have the fiscal space while abnormally high recurrent public expenditures in Solomon Islands are responsible for its low benefit to cost ratio; and, (iv) it is the longevity of the interventions, particularly in the case of 
Timor-Leste, rather than the financial support that is critical to preventing a rollback into conflict on donor-exit. The policy implications of these observations are considered next. The value of this analysis is in its transparency and thus replicability. The robustness of the key finding - that successful interventions require time frames much larger than what has been bandied around - is robust to large changes in the assumed parameters of the model.

\section{Four policy lessons}

Four policy implications are drawn from the findings of the previous section. These are: (i) the timeframe for interventions is longer than what has been envisaged by donors and the intervened; (ii) support for funding of 'state services', and in the main to the recurrent budget, is critical; (iii) budget support could be withdrawn with a simultaneous substitution of domestically generated revenue as part of a transparent process of reverting sovereignty back to the population of the intervened state; and, (iv) incentives for the interveners as much as the intervened to stay the full course have to be built into a compact at the initiation of the intervention/mission. Each of the above-enumerated is elaborated upon next.

First, clarity on a realistic timeframe to exit has several advantages. Knowing what it takes to make a successful exit, both by the donors and the recipient, is likely to encourage a closer scrutiny of the costs and benefits of the planned rescue mission. Knowing what it takes for successful exit, the parties may simply choose not to take this option. Agreeing to participate, knowing the costs, would be a signal of the degree of 
commitment to the mission. When commissioned, a post-conflict assistance mission with a clear time horizon for successful exit of, say, a quarter century opens up several alternative options to the limited menu on offer when the time horizon is either short or unclear. As an example, a perennial problem in post-conflict states is the lack of local capacity and there is the primary task of building this capacity.

In the main, the strategies used thus far have relied heavily on the use of foreign personnel with local counterparts and short 'crash' courses to fill perceived (or otherwise) voids in available local skills. In the case of Solomon Islands, for example, Australian public servants have been posted to Honiara as part of technical assistance for postconflict reconstruction. A select group of local senior public servants were flown to Australia in 2004 for a three-month short course in economic policymaking at the Australian National University. Most of the returnees were then placed as counterparts to the technical assistance team posted from Canberra to Honiara. While these initiatives may have had some success and probably made sense then, ${ }^{12}$ a longer time horizon would have opened up the options of revamping local training, rebuilding schools and colleges, overhauling the school curriculum, and offering more scholarships to school leavers for specialized training abroad. A quarter-century time horizon provides the space to build local capacity from the bottom up. A longer time horizon necessitates milestones to track progress, but it also offers alternative options for improving the effectiveness of donor-support. It creates the space to use progress-based aid (Barder and Birdsall, 2006; Birdsall, et al 2007), as a specific case in point. Most importantly, long-

\footnotetext{
${ }^{12}$ One of the authors who taught these trainees, on a return visit in June 2007, discovered that most of those trained had moved on to other jobs, both at home and abroad.
} 
term interventions of the nature envisaged here require a multilateral intermediary such as the United Nations or World Bank since bilateral arrangements lack credibility over such a time horizon.

Second, state failure is evidenced by the void in provision of and demand for state services. This, as shown in section 2 above, could constitute a trap: states lacking fiscal space are unable to fund the very basic public goods that in turn depress investment and growth of the economy. Post-conflict reconstruction, therefore, entails the lifting of a fragile state out of the low equilibrium trap to a (stable - to avoid a roll-back, and) high equilibrium. While the distinction between recurrent and capital outlays, in our view, is artificial, the fact remains that budgets are and will remain split between the two. Expenditure on salaries and consumables relating to providing basic education and healthcare is part of the recurrent budget when these clearly are investments into building human capital. Donors, however, happily fund the construction of a school building that shelters the child during classes but shy away from funding teacher salaries as this is part of the recurrent budget. In the few exceptions, such funding is provided outside the recurrent budget. The longer time horizon for post-conflict reconstruction provides compelling reasons for budget-support. In this case, donors can lead by funding access to basic public goods, such as the provision of security to person and property that are critical to investment and thus growth of the economy. Tax rates could subsequently be raised, but from a low base, as an explicit compact between the government and the governed for improved access to basic services. Such a compact could form the basis for a transparent process of earning back sovereignty and with it seeing donor presence being 
wound-down. Progress made on being able to fund recurrent provisions from internally generated sources lends itself as a transparent milestone towards exit of donors from having a role in providing public services.

On this last point, the IMF is wrong in pushing for greater taxation early in the postconflict stage to keep the budget balanced in Solomon Islands. This proposal is problematic for several reasons, including the following three: (i) citizens in post-conflict states are deprived of the most basic services; thus increased taxation without a commensurate increase in access to quality public services is imprudent; (ii), a premature rise in taxation is only likely to shrink the tax base, thus could be counter-productive; and (iii), post-conflict states with weak institutions are prone to corruption; thus raising taxes prematurely is only likely to exacerbate the problems of poor governance. ${ }^{13}$ The premature raising of tax rates could already be a problem in Solomon Islands. Amongst the four post-conflict states examined here, Solomon Islands has an unusually high taxto-GDP ratio. This, in all likelihood, is weighing down the growth of the formal economy. It, thus, would make sense to lower the tax rates - as is being done in Liberia, and with some success - with a view to attracting more businesses into the formal economy. The broad message here is that the recurrent budget in post-conflict states could be funded via donor resources with an explicit link to growth of the economy and with it the weaning of such support and the gradual handing back of sovereignty.

\footnotetext{
${ }^{13}$ The Jakarta Post, for example notes in its editorial of $23^{\text {rd }}$ October 2007 that: "[f]or more than three decades now the tax office has been perceived by the public as among the most corrupt public institutions in the country, with many of its officials living conspicuously far beyond their official means.”
} 
Third, the least visible but possibly the most difficult challenge of post-conflict staterebuilding is that of creating and sustaining institutions to maturation given their role in growth (Rodrik, 2004). While the support of donor resources is necessary, and possibly the most visible, the greater value of an extended and assured donor presence in a postconflict state with a clear goal and timeframe for exit is the certainty it brings both to the local population and international investors. Prolonged donor presence with an entire generation having grown up within a functioning state creates norms that could act as a backstop against regression. Regular and sustained access to information on the quantity and quality of services provided, the costs of these provisions, and the sources of funding for them is likely to instill norms within the population that remain when donors have exited the scene.

Part of creating state institutions will involve raising taxes, but this should be part of the bargain for regaining the rights to full sovereignty (see Besley and Persson, 2007; Fearon and Laitin, 2004). An exit strategy with clear milestones to track progress towards exit is likely to mitigate the risks of mission-creep (both on the time frame and breadth of issues covered) on the part of donors and problems of moral hazard on the part of the intervened. We address this issue next.

Fourth, incentives to induce all parties to stay the full course of the compact have to be created. This could be done by building in rewards for abiding by the compact and penalties for defection from the agreed strategy ex-post. The common urge with any rescue is to 'give up' early, particularly when some relief is attained. How can we 
incentivize both the interveners and the intervened to stay the full course to exit?

Addressing this issue is particularly important given the long time frames canvassed in (1) above. We know that states agreeing to such a rescue will be those likely to stay the course, but this on its own may not be enough. We hazard a new proposal: that of a compact between the intervened and the interveners with penalties for a premature bailout by either party. Such a compact would be agreed to at the initiation of the intervention and contain penalties for breach of contract. As an example, the intervened state could pay-out the intervener for the support provided to date to the recurrent budget for a premature bail-out from the program - in essence, they are buying out sovereignty. Similarly, the intervener could bailout of the rescue by paying out the balance of the recurrent budget support in the compact. ${ }^{14}$ A salient message from this section is that 'sovereignty is not free' and neither is the rescue of a failed or failing state. A meaningful and transparent basis for sharing the costs of rescue can be part of a compact for post-conflict reconstruction. What such a compact may look like is part of ongoing work. $^{15}$

\section{Conclusions}

The bulk of this paper has been an accounting exercise. We have estimated the time necessary to enable post-conflict states to grow sufficiently to be able to fund their recurrent budget - the minimal necessary to keep the machinery of the state operating -

\footnotetext{
${ }^{14}$ This is akin to a finite-length marriage contract with transparent conditions for a premature divorce. This exercise, we believe, is best managed multilaterally with any returned funds placed in a 'venture fund' to be used for rescue of the 'next-best' fragile or failed state.

${ }^{15}$ This could build on "Principles for Good International Engagement in Fragile States" by OECD; see: http://www.oecd.org/document/46/0,3343,en_2649_33693550_35233262_1_1_1_1,00.html
} 
this being our criterion for donor-exit. We show that exit from post-conflict states will take decades and cost billions of dollars - a lot more than what was initially envisioned in all of the cases considered here. Clemens and Radelet (2003) come to a similar timeframe for a successful exit of the Millennium Challenge Corporation from states with which it has engaged. We also show that the interventions, at least on strictly costbenefit terms, are worth the outlays in three of the four post-conflict states considered here.

The salient message of the paper is that a lengthy engagement of externals in postconflict states is critical to the creation and maturation of institutions necessary to prevent a rollback into state failure on the departure of the interveners. We have also emphasized the need for donors to support the recurrent budget; not withstanding the fact that the distinction between recurrent and capital outlays in the budget is both artificial and possibly unhelpful.

We turn next to the question of why is it that post-conflict reconstruction is such a lengthy process. The comparisons with the Marshall Plan, on this front, could not be starker. Part of the answer lies in the fact that the post World War II reconstruction was more about rebuilding physical rather than social infrastructure, with the latter being more time (and resource) intensive than the former. Rebuilding physical infrastructure, as the post-2004 tsunami efforts in Asia show, is a relatively quick process. Creating the fiscal space for state viability, as shown here, is time-intensive. State building, similarly, often involves the creation and 'deep-rooting' of institutions and organizations - 
processes that are inherently time consuming. Raising the taxing capacity of the state can be an integral part of institutional strengthening. Absent such lengthy engagements with clear time-frames and milestones for exit, the chances are that a post-conflict state will roll back into conflict (that is, to the 'bad' equilibrium) once external support is withdrawn.

Post-conflict interventions of the $21^{\text {st }}$ Century have involved the rebuilding of both the destroyed physical and social infrastructure. Extended conflicts create self-perpetuating forces - that is, a conflict trap, making it difficult for countries in conflict to muster sufficient fiscal space to provide state services and break-out of their predicament on their own. Poor and limited access to basic services and low levels of income, as demonstrated by the predicament of Liberia, are symptomatic of the above. Civil wars, on average, last some 7 years (Collier, 2007a); a period long enough to destroy many of the institutions of civil society including the memory within the afflicted population of the norms of a functioning state. Donor interventions to extinguish conflicts, and postconflict reconstruction, thus, provide the window of opportunity to lift the afflicted state from the 'bad' to the 'good' equilibrium. Within the latter, the state attains the fiscal space to provide the basic state services such as security to person and property to provide the preconditions for investments and growth of the economy. Meanwhile norms of behavior take root to cement such expectations of the now functioning state. It is the latter that act as a back-stop against rollback into conflict once donor support is withdrawn. 
Success at rebuilding post-conflict states of the $21^{\text {st }}$ Century is less than enviable. While it may be too early to pass judgment on the ongoing post-conflict rescue missions, we have argued for greater clarity in terms of the length of commitment and the goals of such engagement. For the four cases considered here, the commitment of resources and timeframe under consideration fall well short of our estimates of what may be minimally necessary. A longer time frame for engagement in these states and greater clarity on the criteria for exit opens up new options on what may be done in post-conflict reconstruction. This would involve doing different things to those done currently; greater support to the recurrent budget is a case in point. It would also entail the handing back of sovereignty commensurate with the revenue raising capacity of the intervened state- a clearer path to exit than what is visible now. 


\section{References}

Acemoglu, Daron, 2005. "Politics and Economics in Weak and Strong States," Journal of Monetary Economics 52, 1199-1226.

Alesina, Alberto and Enrico Spolaore 2003. The Size of Nations, MIT Press.

Alesina, Alberto and Romain Wacziarg 1998. “Openness, country size and government”, Journal of Public Economics 69: 305-21.

Besley, Timothy and Torsten Persson 2007. "The origins of state capacity: property rights, taxation, and politics”, Working Paper 13028, National Bureau of Economic Research, http://www.nber.org/papers/w13028 (April)

Barder, O and N Birdsall, 2006. "Payments for Progress: A Hands-Off Approach to Foreign Aid”, Working Paper 102, Centre for Global Development, Washington DC.

Birdsall, Nancy; William Savedoff; and, Katherine Vyborny 2007. "Progress-Based Aid for Education: A Hands-Off Approach”, Centre for Global Development, Washington DC.

Centre for Global Development, 2007. “The World Bank’s work in the poorest countries: five recommendations for a new IDA”, Report of the IDA 15 Working Group, June.

Chauvet, Lisa; Paul Collier; and, Anke Hoeffler 2007. "The Cost of Failing States and the Limits to Sovereignty”, Research Paper No. 2007/30, UNU-WIDER.

Clemens, Michael and Steve Radelet 2003. "The Millennium Challenge Account: How much is too much, how long is long enough”, CGD Working paper \# 23.

Collier, P 2007a. "Post-conflict recovery: how should policies be distinctive?”, Centre for the Study of African Economies, Oxford University.

Collier, P 2007b. The Bottom Billion, Oxford University Press, NY.

DFID, 2005. "Why we need to work more effectively in fragile states”, UK Department of International Development, London.

Elbadawi, Ibrahim A; Linda Kaltani; and, Klaus Schmidt-Hebbel 2007. "Post-Conflict Aid, Real Exchange Rate Adjustment, and Catch-up Growth”, World Bank Policy Research Working Paper 4187, April.

EPG, 2005. External Assessment of the Regional Assistance Mission to the Solomon Islands. http://www.ramsi.org/files/epg_report_final.doc.

Fearon, James D. and David D. Laitin, 2004. "Neotrusteeship and the problem of weak States”, International Security 28(4): 5-43.

Fukuama, Francis 2004. “The imperative of state-building”, Journal of Democracy 15(2): 17-31. 
Ghani, Ashraf; Clare Lockhart; Nargis Nehan; and Baqer Massoud 2007. "The budget as the linchpin of the State: Lessons from Afghanistan”, Boyce and O’Donnell (ed) Peace and the Public Purse, Lynne Rienner, USA.

Gilligan, Michael and Ernest J Sergenti 2007. "Do UN Interventions Cause Peace? Using Matching to Improve Causal Inference”, (unpublished), NYU.

IMF, 2006. "Liberia: 2006 Article IV Consultation”, IMF Country Report No. 06/166, May.

IMF, 2007a. "Republic of Mozambique: 2007 Article IV Consultation”, IMF Country Report No. 07/262, (July).

IMF, 2007b. “Solomon Islands: 2007 Article IV Consultation”, IMF Country Report No. 07/304, September.

Leeson, P T 2007. "Efficient anarchy”, Public Choice 130: 41-53.

Murphy, K; A Sliefer; and R Vishny 1989. "Industrialisation and the big push”, Journal of Political Economy 97(5): 1003-26.

North, D 1981. Structure and Change in Economic History. W.W. Norton \& Co, New York.

OECD, 2007. Principles for Good Engagement with Fragile States. (April 2007). http://www.oecd.org/dataoecd/61/45/38368714.pdf

Olson, M.C., 1982. The Rise and Decline of Nations: Economic Growth, Stagflation, and Economic Rigidities. Yale University Press, New Haven, London.

Pacific Islands Forum Eminent Persons Group (EPG), 2005. "A Review of the Regional Assistance Mission to Solomon Islands”, http://www.ramsi.org/files/epg_report_final.doc

Radelet, Steven 2007. “Reviving economic growth in Liberia”, CGD Working Paper \# 133.

Rodrik, Dani 2004. “Getting Institutions Right”, http://ksghome.harvard.edu/ drodrik/ifoinstitutions\%20article\%20_April\%202004_.pdf

Rodrik, Dani; Arvind Subramanian; and, Francesco Trebbi, 2004. "Institutions Rule: The Primacy of Institutions Over Geography and Integration in Economic Development," Journal of Economic Growth 9(2): 131-165

Rodrik, D 1996. "Why do more open countries have bigger government?", NBER Working paper \# 5537, April.

USAID, 2005. Fragile States Strategy. http://www.usaid.gov/policy/2005_fragile_states_strategy.pdf.

World Bank, 2005. World Bank’s Summary of Performance-Based Allocation System for IDA14 http://siteresources.worldbank.org/IDA/Resources/ANNEX1CPIA.pdf 
Table 1: Basic indicators of countries intervened in by external forces since 1990 .

\begin{tabular}{|c|c|c|c|c|c|}
\hline Country & 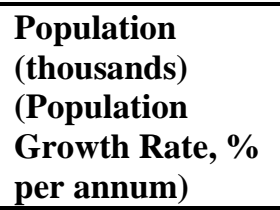 & $\begin{array}{l}\text { GDP Per } \\
\text { Capita } \\
\text { (USD 2000) } \\
(2005) \\
\end{array}$ & $\begin{array}{l}\text { ODA Per } \\
\text { Capita * }\end{array}$ & $\begin{array}{l}\text { Aid (\% of } \\
\text { GNI) }\end{array}$ & $\begin{array}{l}\text { HDI Rank** } \\
\text { (2007 Report) }\end{array}$ \\
\hline Afghanistan & $\begin{array}{l}28,574 \\
(\mathrm{~N} / \mathrm{A})\end{array}$ & N/A & 89.15 & 37.84 & Unranked \\
\hline Angola & $\begin{array}{l}15,941 \\
(2.87) \\
\end{array}$ & 936.87 & 27.65 & 1.54 & 162 \\
\hline Bosnia and Herzegovina & $\begin{array}{l}3,907 \\
(-.06) \\
\end{array}$ & $1,647.32$ & & 5.24 & 66 \\
\hline Burundi & $\begin{array}{l}7,547 \\
(3.58)\end{array}$ & 104.64 & 48.3 & 46.79 & 167 \\
\hline Cambodia & $\begin{array}{l}14,071 \\
(1.96) \\
\end{array}$ & 402.25 & 38.22 & 9.05 & 131 \\
\hline Central African Republic & $\begin{array}{l}4,037 \\
(1.29)\end{array}$ & 227.29 & 20.43 & 6.97 & 171 \\
\hline Haiti & $\begin{array}{l}8,527 \\
(1.43) \\
\end{array}$ & 434.02 & 46.6 & 12.07 & 146 \\
\hline Iraq & N/A & N/A & & N/A & Unranked \\
\hline Liberia & $\begin{array}{l}3,283 \\
(1.31) \\
\end{array}$ & 135.3 & 33 & 54.12 & Unranked \\
\hline Mozambique & $\begin{array}{l}19,792 \\
(1.88)\end{array}$ & 291.67 & 64 & 20.67 & 172 \\
\hline Rwanda & $\begin{array}{l}9,037 \\
(1.73) \\
\end{array}$ & 260.14 & & 27.06 & 161 \\
\hline Solomon Islands & $\begin{array}{l}477 \\
(2.53) \\
\end{array}$ & 676.82 & 412.11 & 66.5 & 129 \\
\hline Sudan & $\begin{array}{l}36,232 \\
(1.98) \\
\end{array}$ & 462.26 & 50.91 & 7.14 & 147 \\
\hline Timor-Leste & $\begin{array}{l}975 \\
(5.36)\end{array}$ & 345.16 & 185.38 & 33.47 & 150 \\
\hline \multicolumn{6}{|c|}{ Selected MDG Indicators } \\
\hline & $\begin{array}{l}\text { Literacy Rate } \\
\text { (age } 15 \text { and } \\
\text { above, for } \\
2006 \text { )*** }\end{array}$ & $\begin{array}{l}\text { Life } \\
\text { Expectancy } \\
\text { at Birth }\end{array}$ & $\begin{array}{l}\text { Infant } \\
\text { Moratlity }\end{array}$ & $\begin{array}{l}\text { Primary } \\
\text { Completion } \\
\text { Rate }\end{array}$ & $\begin{array}{l}\text { Immunization } \\
\text { Rate (DPT 3) }\end{array}$ \\
\hline Afghanistan & 28.09 & N/A & N/A & 32.25 & 76 \\
\hline Angola & 67.41 & 41.42 & 154 & N/A & 47 \\
\hline Bosnia and Herzegovina & 96.66 & 74.41 & 13 & N/A & 93 \\
\hline Burundi & 59.3 & 44.65 & 114 & 35.74 & 74 \\
\hline Cambodia & 73.61 & 57.03 & 68 & 92.31 & 82 \\
\hline Central African Republic & 48.57 & 39.43 & 115 & 22.52 & 40 \\
\hline Haiti & 39.7 & 52.61 & 84 & N/A & 43 \\
\hline Iraq & 74.05 & N/A & N/A & 74.31 & 81 \\
\hline Liberia & 39.2 & 42.47 & 157 & N/A & 87 \\
\hline Mozambique & 33.5 & 41.81 & 100 & 42.02 & 72 \\
\hline Rwanda & 64.9 & 44.12 & 118 & 38.95 & 95 \\
\hline
\end{tabular}




\begin{tabular}{|c|c|c|c|c|c|}
\hline Solomon Islands & N/A & 62.94 & 23.6 & N/A & 80 \\
\hline Sudan & 60.93 & 56.66 & 62 & 49.66 & 59 \\
\hline Timor-Leste & N/A & 56.72 & 51.5 & N/A & 55 \\
\hline Country & $\begin{array}{l}\text { Population } \\
\text { (Thousands) }\end{array}$ & $\begin{array}{l}\text { GDP Per } \\
\text { Capita } \\
\text { (USD 2000) } \\
(2005)\end{array}$ & $\begin{array}{l}\text { ODA Per } \\
\text { Capita }\end{array}$ & $\begin{array}{l}\text { Aid (\% of } \\
\text { GNI) }\end{array}$ & $\begin{array}{l}\text { HDI Rank } \\
\text { (2007 Report) }\end{array}$ \\
\hline Afghanistan & $28574(\mathrm{~N} / \mathrm{A})$ & N/A & 89.15 & 37.84 & Unranked \\
\hline Angola & $15941(2.87)$ & 936.87 & 27.65 & 1.54 & 162 \\
\hline Bosnia and Herzegovina & $3907(-.06)$ & $1,647.32$ & & 5.24 & 66 \\
\hline Burundi & 7547.52 (3.58) & 104.64 & 48.3 & 46.79 & 167 \\
\hline Cambodia & $14071.01(1.96)$ & 402.25 & 38.22 & 9.05 & 131 \\
\hline Central African Republic & 4037.75 (1.29) & 227.29 & 20.43 & 6.97 & 171 \\
\hline Haiti & $8527.78(1.43)$ & 434.02 & 46.6 & 12.07 & 146 \\
\hline Iraq & N/A & N/A & & N/A & Unranked \\
\hline Liberia & $3283.27(1.31)$ & 135.3 & 33 & 54.12 & Unranked \\
\hline Mozambique & $19792.3(1.88)$ & 291.67 & 64 & 20.67 & 172 \\
\hline Rwanda & 9037.69 (1.73) & 260.14 & & 27.06 & 161 \\
\hline Solomon Islands & $477.74(2.53)$ & 676.82 & 412.11 & 66.5 & 129 \\
\hline Sudan & 36232.95 (1.98) & 462.26 & 50.91 & 7.14 & 147 \\
\hline Timor-Leste & $975.54(5.36)$ & 345.16 & 185.38 & 33.47 & 150 \\
\hline \multicolumn{6}{|c|}{ Selected MDG Indicators } \\
\hline & $\begin{array}{l}\text { Literacy Rate } \\
\text { (age } 15 \text { and } \\
\text { above, for 2006) }\end{array}$ & $\begin{array}{l}\text { Life } \\
\text { Expectancy } \\
\text { at Birth } \\
\end{array}$ & $\begin{array}{l}\text { Infant } \\
\text { Moratlity }\end{array}$ & $\begin{array}{l}\text { Primary } \\
\text { Completion } \\
\text { Rate }\end{array}$ & $\begin{array}{l}\text { Immunization } \\
\text { Rate (DPT 3) }\end{array}$ \\
\hline Afghanistan & 28.09 & N/A & N/A & 32.25 & 76 \\
\hline Angola & 67.41 & 41.42 & 154 & N/A & 47 \\
\hline Bosnia and Herzegovina & 96.66 & 74.41 & 13 & N/A & 93 \\
\hline Burundi & 59.3 & 44.65 & 114 & 35.74 & 74 \\
\hline Cambodia & 73.61 & 57.03 & 68 & 92.31 & 82 \\
\hline Central African Republic & 48.57 & 39.43 & 115 & 22.52 & 40 \\
\hline Haiti & 39.7 & 52.61 & 84 & N/A & 43 \\
\hline Iraq & 74.05 & N/A & N/A & 74.31 & 81 \\
\hline Liberia & 39.2 & 42.47 & 157 & N/A & 87 \\
\hline Mozambique & 33.5 & 41.81 & 100 & 42.02 & 72 \\
\hline Rwanda & 64.9 & 44.12 & 118 & 38.95 & 95 \\
\hline Solomon Islands & N/A & 62.94 & 23.6 & N/A & 80 \\
\hline Sudan & 60.93 & 56.66 & 62 & 49.66 & 59 \\
\hline Timor-Leste & N/A & 56.72 & 51.5 & N/A & 55 \\
\hline
\end{tabular}

Source: WDI (Except when noted)

* ODA Per Capita: from OECD DAC. Subracted debt relief and emergency aid. 2005 USD.

** Source: HDI Report 2007-2008 (http://hdr.undp.org/en/media/hdr_20072008_en_complete.pdf)

*** Numbers are from 1990 for Haiti, Liberia, and Mozambique. 
Table 2: Assistance into intervened states

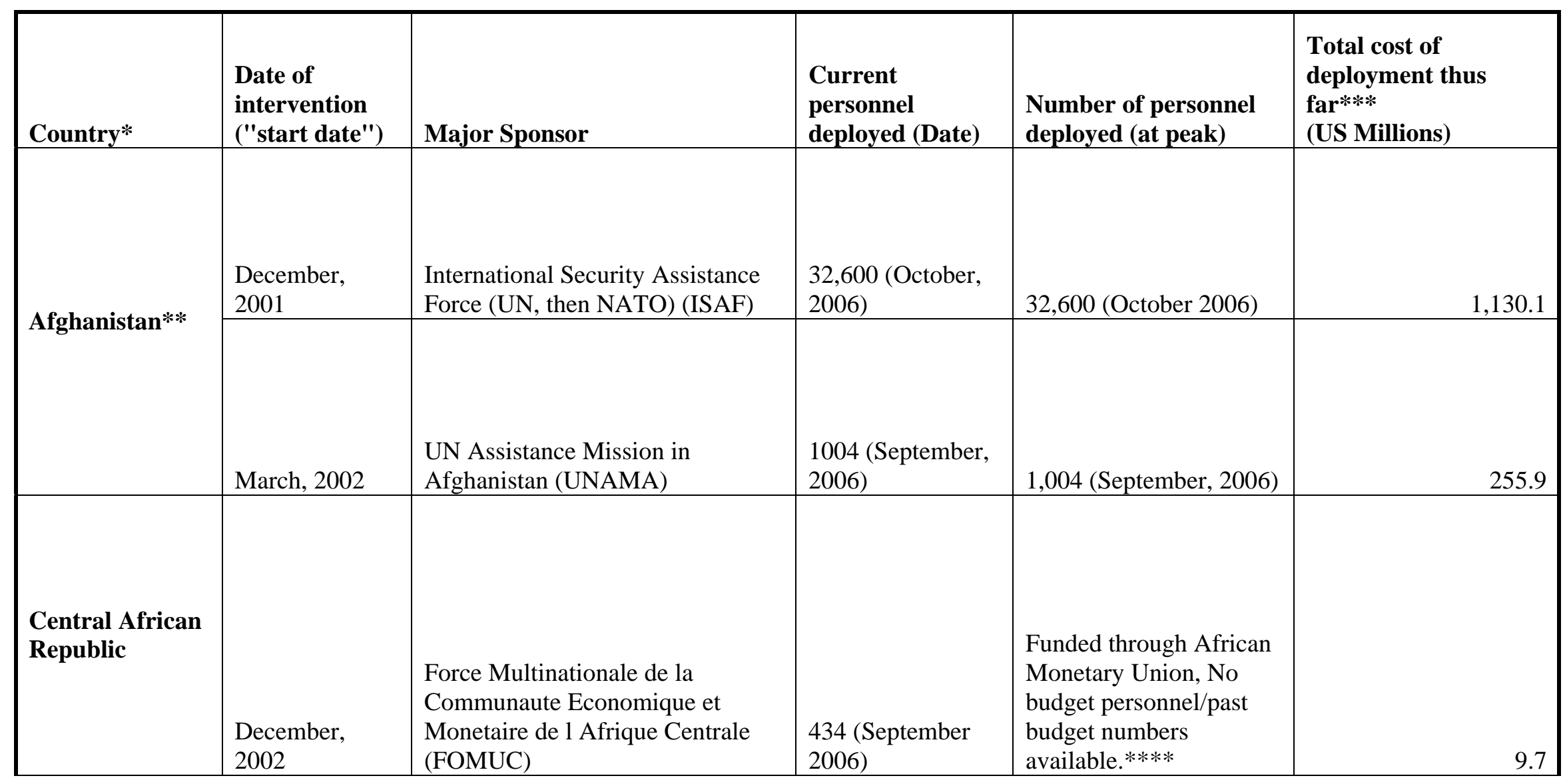




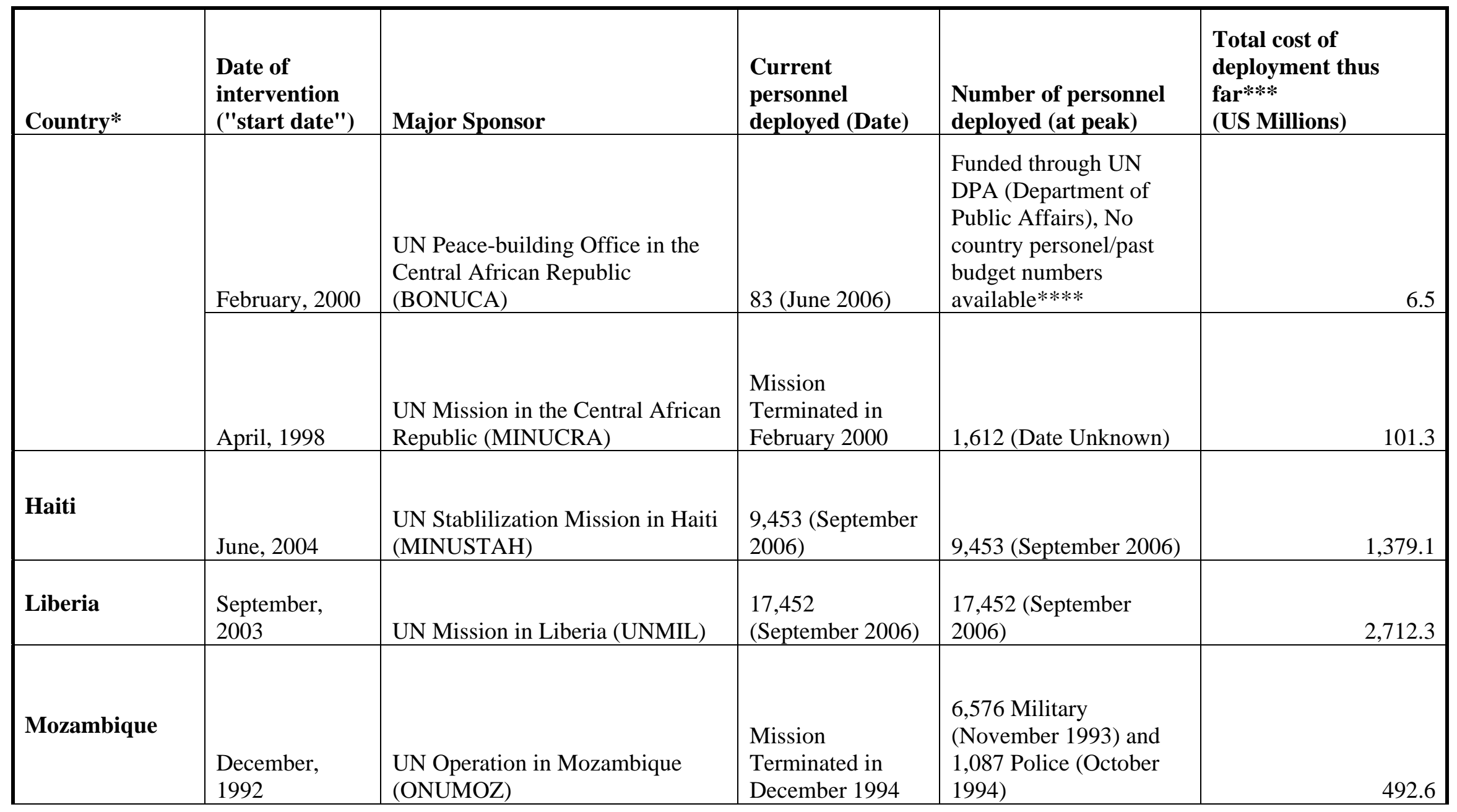




\begin{tabular}{|c|c|c|c|c|c|}
\hline Country* & $\begin{array}{l}\text { Date of } \\
\text { intervention } \\
\text { ("start date") }\end{array}$ & Major Sponsor & $\begin{array}{l}\text { Current } \\
\text { personnel } \\
\text { deployed (Date) }\end{array}$ & $\begin{array}{l}\text { Number of personnel } \\
\text { deployed (at peak) }\end{array}$ & $\begin{array}{l}\text { Total cost of } \\
\text { deployment thus } \\
\text { far*** } \\
\text { (US Millions) }\end{array}$ \\
\hline Solomon Islands & July, 2003 & $\begin{array}{l}\text { Regional Assistance Mission in the } \\
\text { Solomon Islands (RAMSI) }\end{array}$ & $\begin{array}{l}700 \text { (September } \\
\text { 2006) }\end{array}$ & $\begin{array}{l}\text { Funded by RAMSI. No } \\
\text { personnel/past budget } \\
\text { numbers available.**** }\end{array}$ & 159.4 \\
\hline & May, 2006 & Operation Astute & $\begin{array}{l}920 \text { (November } \\
2006)\end{array}$ & 1,300 (May 2006) & $\begin{array}{r}\text { No budget numbers yet } \\
\text { available. }\end{array}$ \\
\hline Total & & & & 80,343 & $7,847.4$ \\
\hline
\end{tabular}

* All data taken from Annual Review of Global Peace Operations (2007). Center for International Cooperation. ** Data for budget taken from UK Armed Forces Documents

(http://www.armedforces.co.uk/mod/listings/10024.html). ***Includes past expenditures plus current budget (for all countries last budget year was 2006, Haiti, Liberia, Timor-Leste last budget year was 2007). $* * * *$ When no past budget numbers were available, simply used the current budget number to estimate total cost of deployment. 
Table 3: Reconstruction Commitments

\begin{tabular}{|l|l|r|}
\hline Country & Pledging Conference (Date) & $\begin{array}{l}\text { Amount Pledged (2005 \$ } \\
\text { billions) }\end{array}$ \\
\hline Afghanistan & Tokyo January 21-22nd, 2002 & 1.834 \\
\hline Angola & Brussels & 1.000 \\
\hline & December 1995 and April & 2.276 \\
\hline Bosnia & 1996 & 0.839 \\
\hline Burundi & Geneva December 2001 & 1.145 \\
\hline Cambodia & Tokyo, June 22nd, 1992 & 1.118 \\
\hline Haiti & Washington, July 20th, 2004 & 2.297 \\
\hline Kosovo & Brussels, July 28th, 1999 & \\
\hline & New York, February 6th, & 0.536 \\
\hline Liberia & 2004 & 0.507 \\
\hline Mozambique & Geneva, February 1987 & 0.271 \\
\hline Rwanda & Geneva, August 2nd, 1994 & 4.500 \\
\hline & Oslo, Norway, April 11th, & 0.588 \\
\hline Sudan & 2005 & $\mathbf{1 6 . 9 1}$ \\
\hline Timor Leste & Tokyo, 1999, Lisbon, 2000 & \\
\hline Total & \multicolumn{2}{|c|}{} \\
\hline Data source: International and National News Sources. Specific citations available from the authors upon request.
\end{tabular}

Table 4: Per Capita GNI and recurrent expenditure, and tax take for 2005.

\begin{tabular}{|l|l|l|l|}
\hline Country & $\begin{array}{l}\text { Per Capita GDP } \\
(2005 \text { USD })\end{array}$ & $\begin{array}{l}\text { Per Capita Recurrent } \\
\text { Expenditure (2005 USD) }\end{array}$ & $\begin{array}{l}\text { Tax Take in 2005 (\% } \\
\text { of GDP) }\end{array}$ \\
\hline Liberia & 167 & 63.13 & 14.5 \\
\hline Mozambique & 335 & 67.20 & 13.6 \\
\hline Solomon Islands & 624 & 545.36 & 24.7 \\
\hline Timor-Leste & 366 & 196.90 & 9.5 \\
\hline
\end{tabular}

Source: GNI and tax take data is from WDI (online) while recurrent expenditure are estimates generated by the authors. Appendix 2 provides details on the last.

Table 5: Year of and tax-take at exit, and cost-benefit ratios - best case scenario.

\begin{tabular}{|l|l|l|l|l|}
\hline Country & $\begin{array}{l}\text { Year of donor } \\
\text { exit }\end{array}$ & $\begin{array}{l}\text { Tax take at exit } \\
\text { (percent of GDP) }\end{array}$ & $\begin{array}{l}\text { Cost (\$m, USD } \\
\text { from 2005) }\end{array}$ & $\begin{array}{l}\text { Benefit: Cost } \\
\text { (ratio) }\end{array}$ \\
\hline Liberia & 2018 & 21 & 761 & $10: 1$ \\
\hline Mozambique & 2010 & 16 & 805 & $57: 1$ \\
\hline Solomon Islands & 2028 & 29 & 1982 & $1: 2$ \\
\hline Timor-Leste & 2026 & 20 & 2051 & $1: 1$ \\
\hline
\end{tabular}

Source: Authors' estimates. 
Table 6: Historical rates of growth - compound annual rates at end points

\begin{tabular}{|l|r|r|l|l|l|}
\hline & & & $\begin{array}{l}\text { GDP } \\
\text { Growth } \\
\text { Rate } \\
\text { Ten } \\
\text { Year } \\
\text { Pre } \\
\text { Country }\end{array}$ & $\begin{array}{l}\text { GDP } \\
\text { Growth } \\
\text { Rate } \\
\text { Post } \\
\text { Conflict } \\
\text { Conflict }\end{array}$ & $\begin{array}{l}\text { End of } \\
\text { Conflict } \\
\text { Conflict } \\
\text { fonflict } \\
\text { growth } \\
\text { computation }\end{array}$ \\
\hline Afghanistan & 2001 & 2001 & N/A & N/A & \\
\hline $\begin{array}{l}\text { Central African } \\
\text { Republic }\end{array}$ & 1996 & 1998 & $-2.06 \%$ & $-1.02 \%$ & $\begin{array}{l}(1998 \text { to } \\
2005)\end{array}$ \\
\hline Haiti & 2004 & 2004 & $-0.65 \%$ & $0.27 \%$ & $\begin{array}{l}(2004 \text { to } \\
2005)\end{array}$ \\
\hline Liberia & 1989 & 2003 & $-3.72 \%$ & $1.95 \%$ & $\begin{array}{l}(2003 \text { to } \\
2005)\end{array}$ \\
\hline Mozambique & 1975 & 1992 & N/A & $4.94 \%$ & $\begin{array}{l}(1992 \text { to } \\
2005)\end{array}$ \\
\hline Solomon Islands & 1999 & 2003 & $0.67 \%$ & $2.48 \%$ & $\begin{array}{l}(2003 \text { to } \\
2005)\end{array}$ \\
\hline Timor-Leste & 1999 & 2000 & N/A & $-2.60 \%$ & $\begin{array}{l}(2000 \text { to } \\
2005)\end{array}$ \\
\hline
\end{tabular}

Notes: Growth rate computed as average of the annual compound rate from beginning to end of period.

Table 7: Year of and tax-take at exit, and cost-benefit ratios - based on historical (post conflict) annualized average growth rate.

\begin{tabular}{|l|l|l|l|l|}
\hline $\begin{array}{l}\text { Country } \\
\text { (post-conflict per } \\
\text { capita growth rate) }\end{array}$ & Year of donor exit & $\begin{array}{l}\text { Tax take at exit } \\
\text { (percent of } \\
\text { GDP) }\end{array}$ & $\begin{array}{l}\text { Cost (\$m, } \\
\text { USD from } \\
\text { 2005) }\end{array}$ & $\begin{array}{l}\text { Benefit: Cost } \\
\text { (ratio) }\end{array}$ \\
\hline $\begin{array}{l}\text { Liberia } \\
(1.95 \%)\end{array}$ & 2027 & 26 & 1200 & $7: 1$ \\
\hline $\begin{array}{l}\text { Mozambique } \\
(4.9 \%)\end{array}$ & 2010 & 16 & 811 & $57: 1$ \\
\hline $\begin{array}{l}\text { Solomon Islands } \\
(2.48 \%)\end{array}$ & 2046 & 33 & 2709 & $1: 2$ \\
\hline $\begin{array}{l}\text { Timor-Leste } \\
(-2.6 \%)\end{array}$ & $+\infty$ & 40 (ceiling?) & $6563(?)$ & $1: 4(?)$ \\
\hline
\end{tabular}

Notes: Growth estimate for Mozambique of 4.94 percent instead of 5 has been assumed as shown in Table 6 above. Source: Authors' estimates.

Figure 1: Per Capita Government expenditure and per capita GDP, 115 countries 


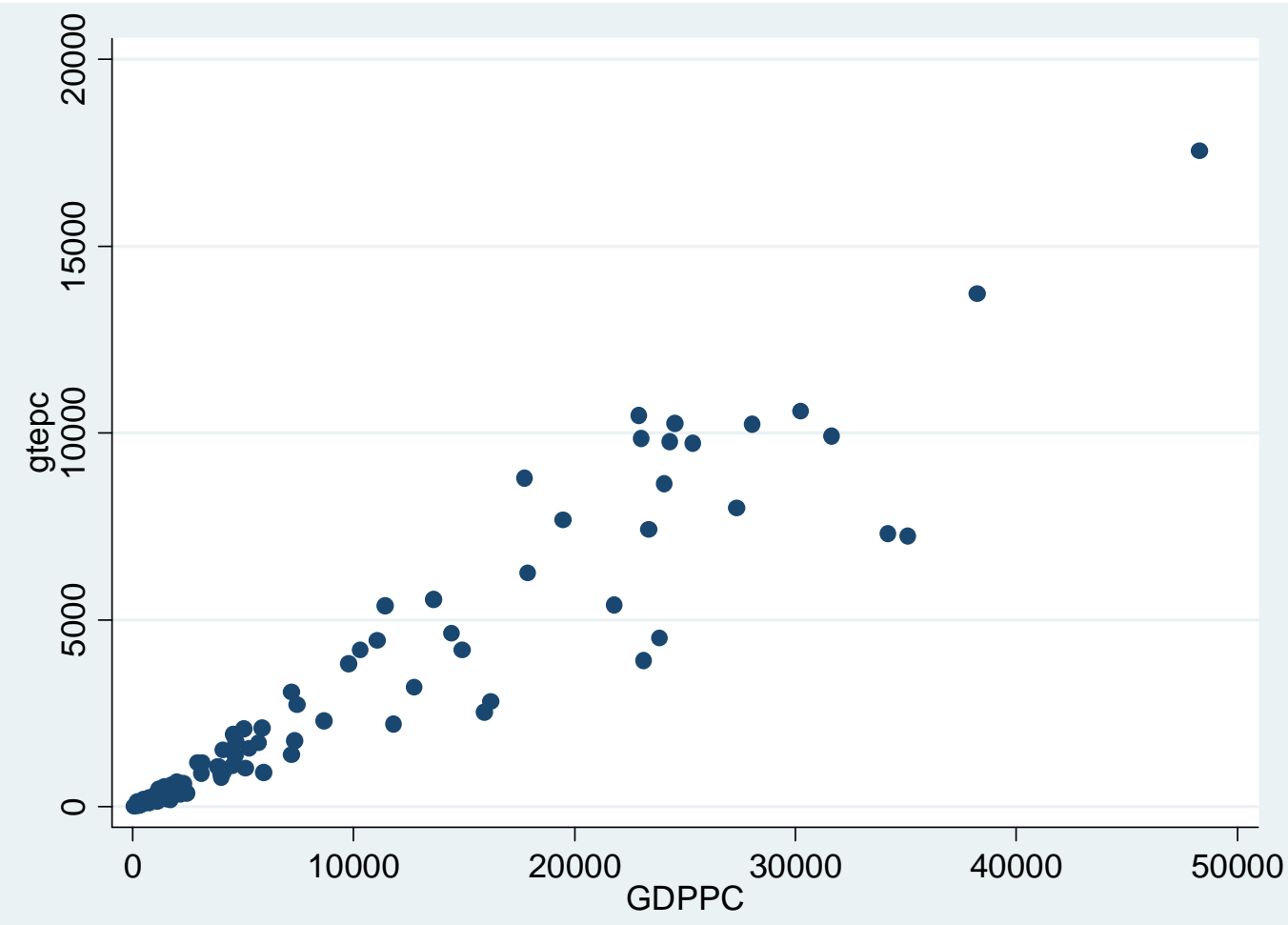

Note: gtepc denotes government total per capita consumption expenditure; GDPPC denotes per capita GDP; and, both variables are measured in 2000 US\$. See Appendix for details on sources of the data. 
Figure 2: Evolution of per capita GDP (2000 \$), pre and post conflict

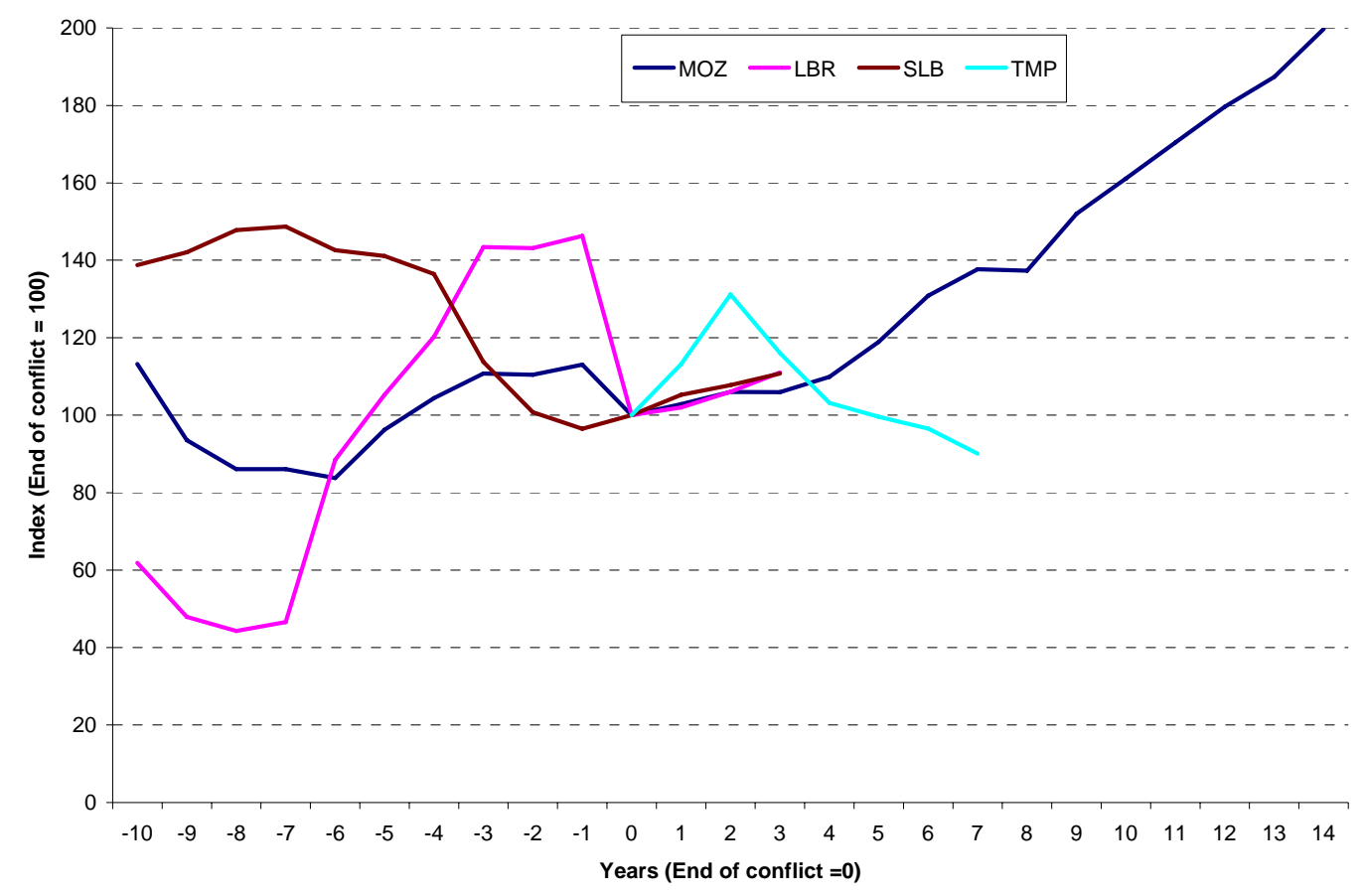

Notes: Intervention marks Year $=0$, this being 1992 for Mozambique (MOZ), 2003 for Liberia (LBR) and the Solomon Islands (SLB), and 1999 for East Timor (TMP); absence of data for Liberia and East Timor disallows the above to be depicted in purchasing power parity adjusted terms. Data source: World development Indicators (online), accessed on 28 September, 2007. 
Figure 3: Per capita government expenditure and aid inflows - Mozambique

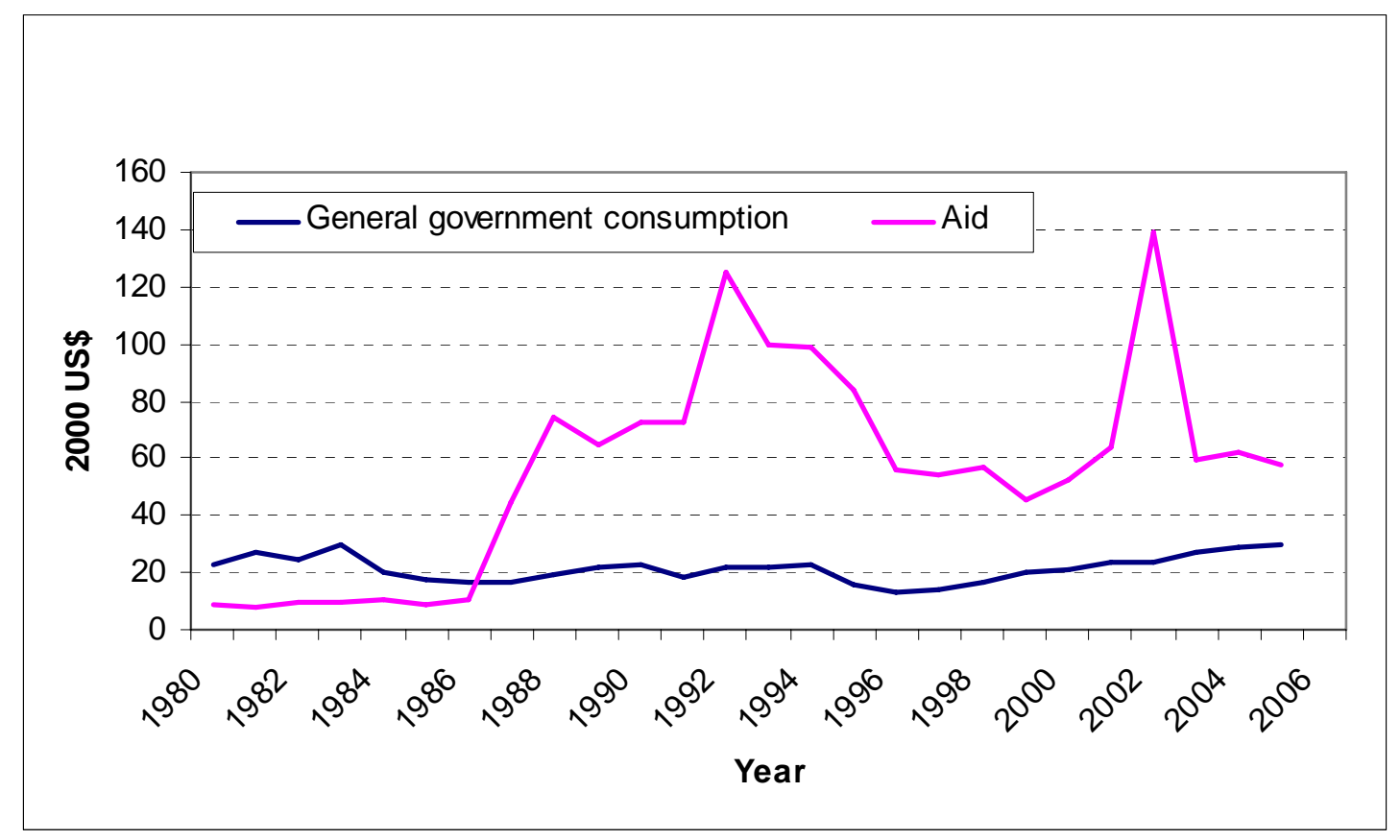

Aid spike from 2000 to 2003 due to devastating floods, reported as the worst in 50 years, that hit the country in February and March of 2000 - see IMF, 2007 (page 12). The 2005 per capita government expenditure in $2000 \$$ is 91 ; this value is assumed as the minimal necessary (the steady state value) to enable the state provide basic (state) services. 
Figure 4: Evolution of per capita GDP for Liberia, 1980 to 2006

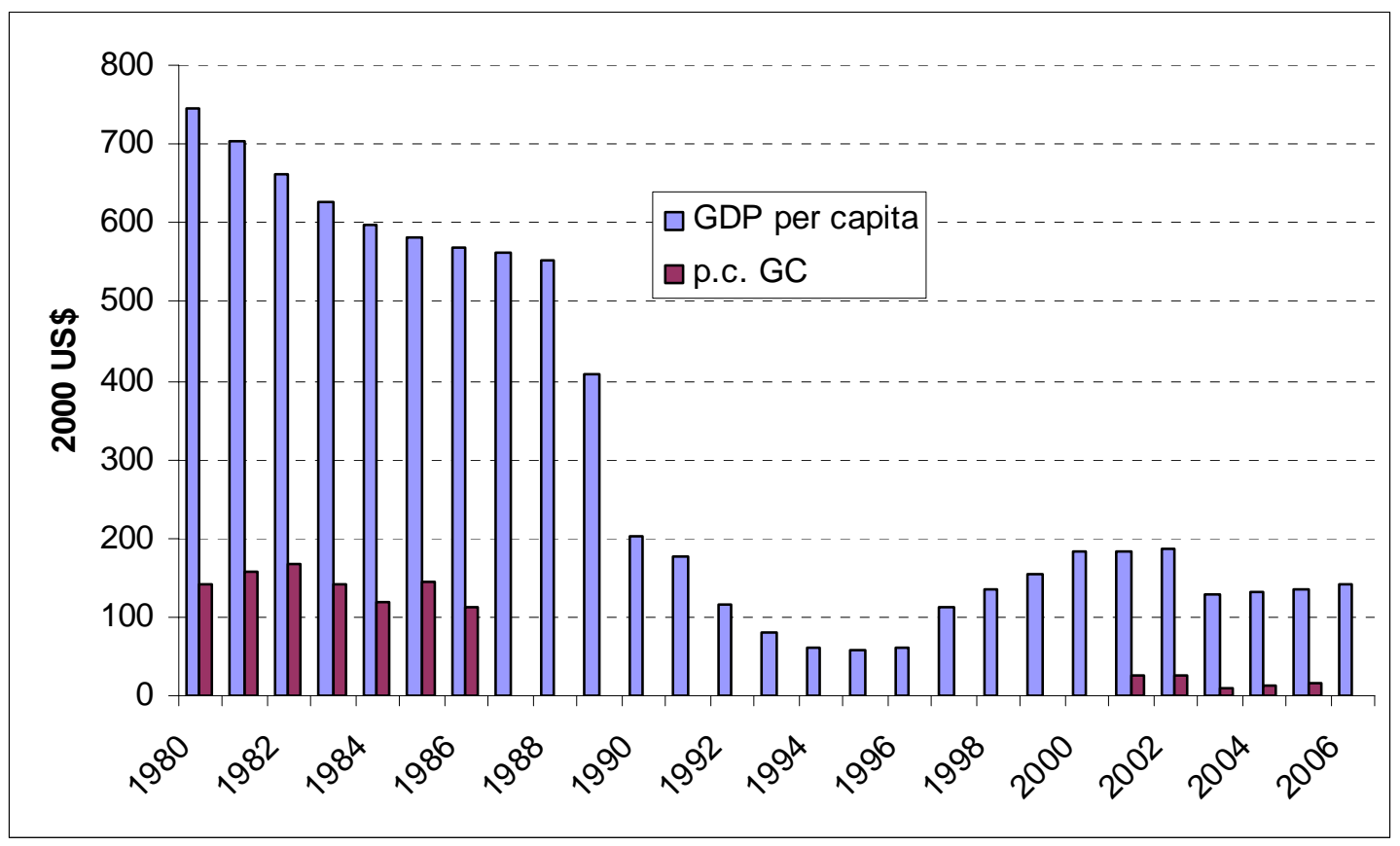

Data source: World Development Indicators database (online). Notes: p.c. GC denotes per capita government consumption.

Figure 5: Tax rate, per capita GDP, tax revenues, and revenue-gap - Mozambique 


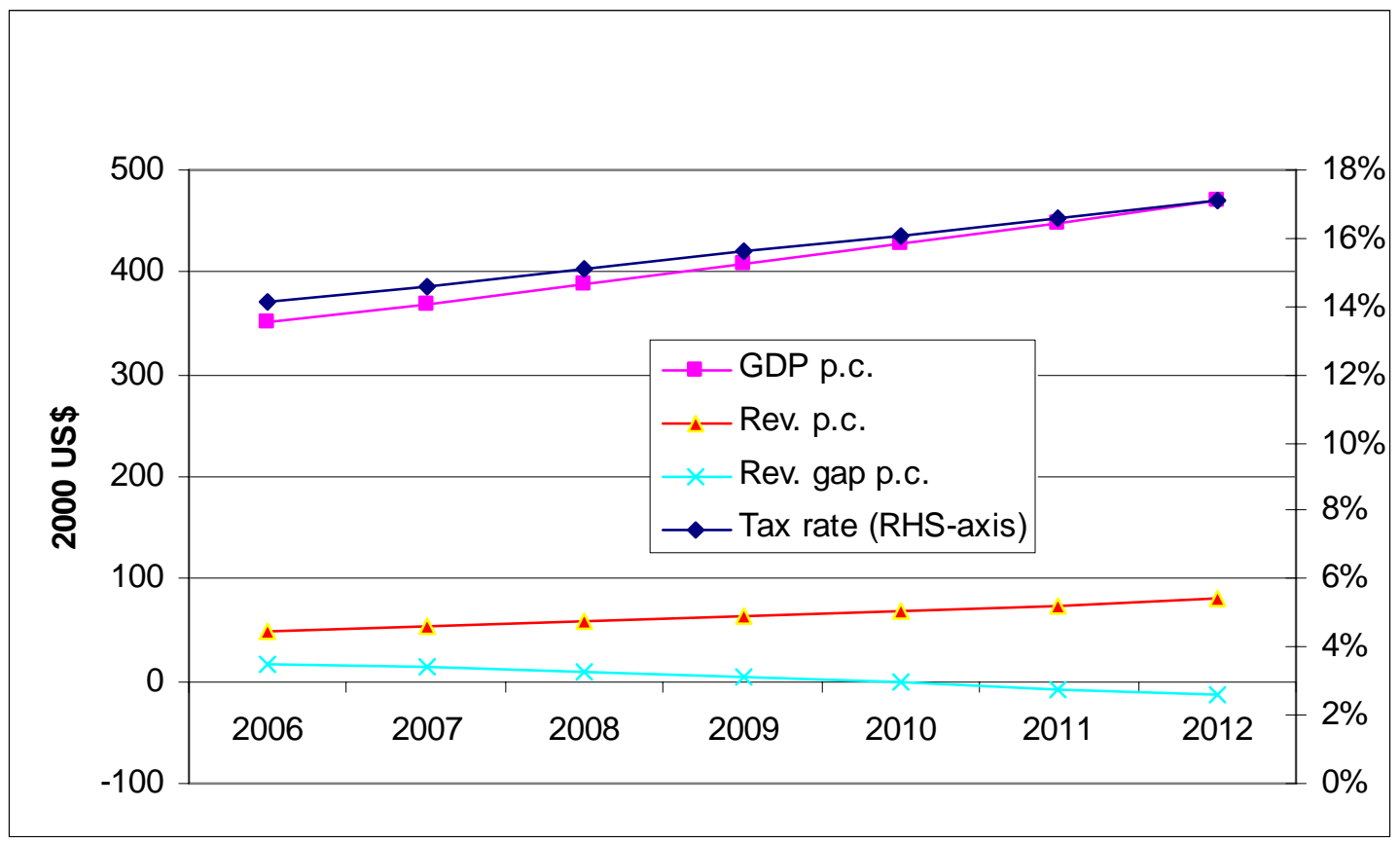

The starting values for per capita GDP and average tax take as a percent of GDP is for 2005. The values for the subsequent years are generated with the assumption that taxtake as a share of GDP rises by half a percentage point each year and that per capita GDP growth is maintained at 5 percent per annum. See Table 4 for assumptions regarding tax take and recurrent outlays.

Source: authors' estimates 


\section{Data Appendix I}

Table A1: Variable names and descriptions

\begin{tabular}{|c|c|c|}
\hline Variable & Description & $\begin{array}{l}\text { Units of } \\
\text { measurement }\end{array}$ \\
\hline Expense & $\begin{array}{l}\text { Expense is cash payments for operating activities of the } \\
\text { government in providing goods and services. It includes } \\
\text { compensation of employees (such as wages and salaries), } \\
\text { interest and subsidies, grants, social benefits, and other } \\
\text { expenses such as rent and dividends. } \\
\text { International Monetary Fund, Government Finance } \\
\text { Statistics Yearbook and data files, and World Bank and } \\
\text { OECD GDP estimates. }\end{array}$ & $\begin{array}{l}\text { Percent of } \\
\text { GDP }\end{array}$ \\
\hline $\begin{array}{l}\text { Govt. } \\
\text { Consumption }\end{array}$ & $\begin{array}{l}\text { Series: General government final consumption } \\
\text { expenditure (\% of GDP) (NE.CON.GOVT.ZS) } \\
\text { General government final consumption expenditure } \\
\text { (formerly general government consumption) includes all } \\
\text { government current expenditures for purchases of goods } \\
\text { and services (including compensation of employees). It } \\
\text { also includes most expenditures on national defense and } \\
\text { security, but excludes government military expenditures } \\
\text { that are part of government capital formation. } \\
\text { Source: World Bank national accounts data, and OECD } \\
\text { National Accounts data files. }\end{array}$ & $\begin{array}{l}\text { Percent of } \\
\text { GDP }\end{array}$ \\
\hline $\begin{array}{l}\text { GDP } \\
(\$ 2000)\end{array}$ & $\begin{array}{l}\text { GDP at purchaser's prices is the sum of gross value } \\
\text { added by all resident producers in the economy plus any } \\
\text { product taxes and minus any subsidies not included in } \\
\text { the value of the products. It is calculated without making } \\
\text { deductions for depreciation of fabricated assets or for } \\
\text { depletion and degradation of natural resources. Data are } \\
\text { in constant } 2000 \text { U.S. dollars. Dollar figures for GDP are } \\
\text { converted from domestic currencies using } 2000 \text { official } \\
\text { exchange rates. For a few countries where the official } \\
\text { exchange rate does not reflect the rate effectively applied } \\
\text { to actual foreign exchange transactions, an alternative } \\
\text { conversion factor is used. } \\
\text { World Bank national accounts data, and OECD National } \\
\text { Accounts data files. }\end{array}$ & $\begin{array}{l}\text { Constant } \\
2000 \text { US\$ }\end{array}$ \\
\hline $\begin{array}{l}\text { GDP per } \\
\text { capita (\$, } \\
2000)\end{array}$ & $\begin{array}{l}\text { GDP per capita is gross domestic product divided by } \\
\text { midyear population. GDP is the sum of gross value } \\
\text { added by all resident producers in the economy plus any } \\
\text { product taxes and minus any subsidies not included in } \\
\text { the value of the products. It is calculated without making } \\
\text { deductions for depreciation of fabricated assets or for } \\
\text { depletion and degradation of natural resources. Data are }\end{array}$ & $\begin{array}{l}\text { Constant } \\
2000 \text { US\$ }\end{array}$ \\
\hline
\end{tabular}




\begin{tabular}{|c|c|c|}
\hline & $\begin{array}{l}\text { in constant U.S. dollars. } \\
\text { World Bank national accounts data, and OECD National } \\
\text { Accounts data files. }\end{array}$ & \\
\hline $\begin{array}{l}\text { GDP, PPP \$, } \\
2000\end{array}$ & $\begin{array}{l}\text { PPP GDP is gross domestic product converted to } \\
\text { international dollars using purchasing power parity rates. } \\
\text { An international dollar has the same purchasing power } \\
\text { over GDP as the U.S. dollar has in the United States. } \\
\text { GDP is the sum of gross value added by all resident } \\
\text { producers in the economy plus any product taxes and } \\
\text { minus any subsidies not included in the value of the } \\
\text { products. It is calculated without making deductions for } \\
\text { depreciation of fabricated assets or for depletion and } \\
\text { degradation of natural resources. Data are in constant } \\
2000 \text { international dollars. } \\
\text { World Bank, International Comparison Program } \\
\text { database. }\end{array}$ & $\begin{array}{l}\text { Constant } \\
2000 \\
\text { International } \\
\$\end{array}$ \\
\hline $\begin{array}{l}\text { Revenue, } \\
\text { excluding } \\
\text { grants }\end{array}$ & $\begin{array}{l}\text { Revenue is cash receipts from taxes, social contributions, } \\
\text { and other revenues such as fines, fees, rent, and income } \\
\text { from property or sales. Grants are also considered as } \\
\text { revenue but are excluded here. } \\
\text { International Monetary Fund, Government Finance } \\
\text { Statistics Yearbook and data files, and World Bank and } \\
\text { OECD GDP estimates. }\end{array}$ & $\%$ of GDP \\
\hline Tax revenue & $\begin{array}{l}\text { Tax revenue refers to compulsory transfers to the central } \\
\text { government for public purposes. Certain compulsory } \\
\text { transfers such as fines, penalties, and most social security } \\
\text { contributions are excluded. Refunds and corrections of } \\
\text { erroneously collected tax revenue are treated as negative } \\
\text { revenue. } \\
\text { International Monetary Fund, Government Finance } \\
\text { Statistics Yearbook and data files, and World Bank and } \\
\text { OECD GDP estimates. }\end{array}$ & \% of GDP \\
\hline
\end{tabular}

Source: World Development Indicators (online) database

Table A1: Summary statistics on variables used, full country sample (2000-04)

\begin{tabular}{|l|l|l|l|l|l|}
\hline Variable & $\begin{array}{l}\text { Obs } \\
\mathbf{( \$ )}\end{array}$ & Mean (\$) & CoV.(\%) & Min (\$) & Max (\$) \\
\hline GDP per capita (2000\$) & 185 & 6345 & 147 & 85 & 48298 \\
\hline GDP per capita (2000\$ PPP) & 169 & 8905 & 107 & 565 & 49594 \\
\hline $\begin{array}{l}\text { Govt. per capita } \\
\text { consumption expenditure } \\
(2000 \$)\end{array}$ & 115 & 2443 & 144 & 7 & 17545 \\
\hline Expense (\% of GDP) & 118 & 27 & 37 & 8 & 54 \\
\hline Revenue (\% of GDP) & 119 & 26 & 42 & 5 & 53 \\
\hline
\end{tabular}

Note: $\mathrm{CoV}$ denotes coefficient of variation. 


\section{Appendix II: Explanatory notes on how recurrent outlays were computed}

Recurrent outlays as of 2005 have been computed by combining data from government budgets, IMF Article IV reports, and the Development Assistance Committee (DAC) database. The level of "recurrent expenditures" for 2005 is the sum total of expenditures on recurrent provisions by the state and the donors. Data for the first of the above has been extracted from the budget. Data on the second has been extracted from DAC database.

\section{$\underline{\text { East Timor }}$}

In the case of Timor-Leste, the fiscal year is from July $1^{\text {st }}$ to the $30^{\text {th }}$ of June. Thus, the average of 2004-2005 and 2005-2006 budget figures were used to calculate recurrent expenditures for the 2005 calendar year. This data was derived from The Democratic Republic of Timor-Leste Combined Sources Budget 2004-2005: Budget Paper Number One (May 2004).

\section{$\underline{\text { Liberia }}$}

Liberia's fiscal year is also from July $1^{\text {st }}$ to $30^{\text {th }}$ of June. Here, we use Liberia's 20062007 recurrent budget expenditures since those for 2004-2005 and 2005-2006 are not unavailable. The 2006 figures were deflated by 7.25 percent, the average reported inflation for the period, to get recurrent expenditures in 2005-dollars. The level of extrabudgetary donor funding of recurrent outlays is calculated as the difference between the reported figures for 'extraordinary ordinary revenues' in the budget and that reported by DAC but net of emergency aid. 


\section{Mozambique}

Mozambique’s fiscal year extends from January $1^{\text {st }}$ to December $31^{\text {st }}$. We use

Mozambique’s 2005 budget. ${ }^{16}$ Recurrent outlays are calculated as Despesa para

Funcionamento (Operational Expenditures) net of Despesas de Capital (Capital

Expenditures). The resulting figures are converted from Meticais to U.S. Dollars using

an average of IMF exchange rates for the end 2004 and 2005. Table A (p 3) of the

Budget also lists grants and loans, so we are able to perform the same calculation

concerning ODA that we made for Liberia. ${ }^{17}$

\section{Solomon Islands}

For Solomon Islands, budget figures were extracted from the Central Bank of the

Solomon Islands website. ${ }^{18}$ These figures were converted into US dollars using an average of IMF exchange rates for 2004 and 2005. A similar exercise to that carried out for Liberia and Mozambique was done to calculate the level of extra-budgetary support provided by donors to fund recurrent provisions.

\footnotetext{
${ }^{16}$ Available online at http://www.govnet.gov.mz/docs_gov/orcamento/fo_oge2005/).

${ }^{17}$ We assume that all loans Mozambique lists are counted as ODA, in keeping with the principle of estimating conservative recurrent expenditures per person to yield lower-bound estimates of time to exit. ${ }^{18}$ http://www.cbsi.com.sb/fileadmin/PDF/reports/Areports/2006AR.pdf, page 38.
} 